Insightful Insiders? Insider Trading and Stock Return Around Debt Covenant Violation

Disclosures

\begin{abstract}
This paper documents significant trading by insiders around a first-time debt covenant violation disclosure in an SEC filing, and is interesting from a research and regulatory standpoint because of three considerations-delay and relative infrequency of new covenant violation disclosures, lack of attention to disclosure issues by regulators, and dearth of research. Importantly, we find a lead relation between net insider selling in the 12 months before a debt covenant violation disclosure and investors' negative returns and net insider buying up to 12 months after disclosure and investors' positive returns. This relation is robust to the presence of other information. These results support our contention that insiders' trades around a covenant violation disclosure may benefit from an information advantage unavailable to other market participants. The aggregate return to insiders-the sum of the losses avoided from selling and the gains from buying-approaches almost two billion dollars over an eight-year study period.
\end{abstract}

JEL Classification:

G14, G32, G38, M41, M48, K22, K42

Keywords:

Insider trading, Debt covenant violation disclosure, SEC regulation, Insider trading enforcement, Event study. 


\section{Insightful Insiders? Insider Trading and Stock Return Around Debt Covenant Violation Disclosures}

\section{Introduction}

Insider filings with the Securities and Exchange Commission (SEC) continue to interest investors as a potential source of new information about a company, predicated on the belief that some insiders' trades might reveal new insights about company prospects. Analysts and other information intermediaries invest substantially in tracking and analyzing insider filings, also in the belief that insiders might earn excess stock return as better-informed investors. Empirical studies (cited below) buttress these beliefs by documenting numerous instances of profitable trading by insiders that cannot be explained by luck (or outsiders' ignorance) but, rather, by access to superior information.

This paper examines insider trading around the disclosure of a first-time debt covenant violation in an SEC filing. ${ }^{1}$ Three considerations motivate our investigation-delay and relative infrequency of a new covenant violation disclosure, dearth of research, and lack of attention to prompt disclosure by regulators. First, companies tend to disclose debt covenant violations with delay, which means that much of the information about the violation remains non-public through the covenant renegotiation process and tends to be publicly disclosed only later, in most cases in an SEC filing that reports the negotiated outcome following the actual violation, such as a covenant waiver, debt renegotiation, or other restructuring disclosure. Indeed, companies most often a disclose a covenant violation in a 10-K

\footnotetext{
${ }^{1}$ Such disclosures typically report the reason for violation (e.g., losses), violation type (e.g., technical, debt service), and the status of covenant negotiation (e.g., covenant waiver, loan modification). As reported in Gopalakrishnan and Parkash (1995), Dichev and Skinner (2002), and Demiroglu and James (2010), and as reflected in our sample and discussed further in section 2.1, by far the largest majority of covenant violation disclosures report a technical violation ( $96.0 \%$ of our sample) and a covenant waiver ( $78.2 \%$ of our sample).
} 
or 10-Q, the conform date of which (end of reporting period) can precede the filing date by up to 90 days $(10-\mathrm{K})$ or 45 days $(10-\mathrm{Q}){ }^{2}$ Companies also tend to make first-time covenant violation disclosures relatively infrequently compared to earnings and other regular announcements, and in a non-standard text form. ${ }^{3}$ Such non-standard disclosure format may hinder investors' full understanding of the underlying details. The simultaneous disclosure in a $10-\mathrm{K}$ or $10-\mathrm{Q}$ filing of regular items such as earnings and dividends news-for which investors (and the financial media) have clearer expectations as to timing and amount-may further hinder investors' complete understanding of a covenant violation disclosure. We contend that the combination of these factors can create the motive and opportunity for insiders to trade before public disclosure of, and market reaction to, a debt covenant event that might prompt the earlier trade.

Second, our literature search finds no study of insider trading around less obvious or infrequent events such as a debt covenant violation disclosure. In contrast, that same search reveals a steady stream of work on insider trading before and after regular and publicized events, much of them accounting related. ${ }^{4}$ Accounting studies include insider trading around earnings announcements (Elliott et al. 1984, Givoly and Palmon 1985, Park et al, 1995, Udpa 1996, Ke et al. 2003, Huddart et

\footnotetext{
${ }^{2}$ As noted in section 2.1 and table 1, a small minority use the Form 8-K (6.3\% of our sample). For accelerated $10-\mathrm{K}$ and 10-Q filers, the maximum delay would be 60 and 35 days, respectively (SEC 2002b).

${ }^{3}$ Nini et al. (2009b) report that $10-20 \%$ of U. S. companies violate a covenant in a given year, although most of these are repeat violations. A much smaller percentage of their sample (2\%) represents first-time violation disclosures.

${ }^{4}$ Our references to the insider trading literature are intended to identify examples of relevant work only, and not present a comprehensive survey.
} 
al. $2007^{5}$, Jagolinzer and Roulstone 2008, Kolasinski and Li 2010), cash flow realizations (Piotroski and Roulstone 2005), earnings forecast revisions (Penman 1982), analysts' recommendations or earnings forecasts (Lustgarten and Mande 1995, Hsieh et al. 2005), and earnings management propensity (Beneish et al. 2001). The finance literature examines insider trading and/or stock returns around numerous other publicized events as well, such as the insider trading event day (Seyhun 1986, 1988, Datta and Datta 1996, Atkas et al. 2008), takeovers (Seyhun 1990, Louis et al. 2010), new equity offerings (Karpoff and Lee 1991), dividend changes (John and Lang 1991), stock repurchases (Lee et al. 1992), bankruptcy filings (Seyhun and Bradley 1997), federal regulations (Garfinkel 1997) and, more recently, market crashes (Marin and Olivier 2008). We find this imbalance surprising-and noteworthy-because insider trading around relatively infrequent and/or less-publicized events could, in fact, be more profitable. For example, for such events, we would expect less-than-comprehensive company blackout rules and regulatory inattention to lower insiders' jeopardy costs from adverse publicity and legal action. ${ }^{6}$ Insiders' incentives to trade could also be affected by enforcement activity. But questionable insider trading would likely be difficult to identify and enforce because of an

\footnotetext{
${ }^{5}$ Huddart et al. (2007) also examine insider trading around the filing date of a 10-K or 10-Q as an event of interest because "it occurs frequently and regularly" (Huddart et al. 2007, p. 5), but do not single out covenant violation disclosures as a unique disclosure of interest.

${ }^{6}$ In addition to enforcement by regulators, insider trading issues can also arise regarding access to non-public information by members of creditors' committees in debt renegotiation (and bankruptcy) who possess confidential information. Some creditor committee members who wish to trade obtain a "big boy" letter from the party who does not have the confidential information, which essentially waives that party's right to sue for lost profits from trading with the insider. The court, however, questioned the protections of "big boy" letters in $\mathrm{R}^{2}$ Investments v. Salamon Smith Barney and Jeffries, but this case was settled in 2007 (Siegel and Hall 2008).
} 
arguably tenuous link between the unfavorable covenant violation event and the basis or cause of the earlier insider trading, which is one reason that regulators might eschew such efforts. ${ }^{7}$

For these reasons, we investigate three issues. First, we examine insider-trading behavior 12 months before and 12 months after a covenant violation disclosure. Given that companies experience deteriorating operating and debt conditions preceding such disclosure (Beneish and Press 1993, Sweeney 1994, Nini et al. 2009b), and that a covenant violation disclosure can resolve stock market uncertainty about the debt and covenant violation renegotiations, we expect that insiders on average will sell before and buy after such an event. ${ }^{8}$

Additionally, we reason that rather than buying or selling based on private information that predicts a negative short-term response to the disclosure (the focus of much insider trading research and regulation), insiders and, possibly, other informed investors interpret such covenant disclosures in the broader context of the benefits of debt and covenant renegotiation, whereby creditors' increase their governance and control rights relative to shareholders, which leads to more effective financial and

\footnotetext{
${ }^{7}$ Our search of several data bases (Lexis-Nexis, Stanford Class Action Clearing House, SEC.gov) reveals no evidence of allegations of a violation of federal insider trading law regarding a loan covenant violation. Under federal law, insider trading violations may lead to an SEC enforcement action under the Insider Trading Sanctions Act of 1984, and traders can seek to recover improper gains under the Insider Trading and Securities Fraud Enforcement Act of 1988. The Department of Justice can also bring a criminal prosecution. Insider trading allegations can also arise in debt renegotiation and bankruptcy when members of creditors' committees have access to confidentital information (note 6). Finally, we comment that under the Private Securities Litigation Reform Act of 1995 some securities class action lawsuits use abnormal insider trading as strong evidence to infer a wrongful state of mind (scienter). But these actions allege accounting and disclosure fraud not insider trading (Griffin and Grundfest 2002, Veliotis 2010). See, also, Huddart et al. (2007, note 4) regarding a lack of insider trading enforcement cases or administrative actions for SEC filings in general, and Marin and Olivier (2008) for a summary of insider trading cases.

${ }^{8}$ Section 3.5 of this paper examines the patterns of eight key financial performance measures for four quarters before and after a covenant violation discsloure.
} 
investment decision making (Nini et al. 2009a, Nini et al. 2009b, Roberts and Sufi 2009, Lan et al.

2010). Seen in this way, covenant violation disclosures represent a potential tipping point towards

uncertainty resolution of and potential improvement in company liquidity and profitability and

investor confidence through increased creditor involvement. Those who participate in the debt and

covenant renegotiation process such as insiders (and creditors) are likely the first to learn about and

understand the implications of this information.

Thus, we contend that insiders buy and sell around a covenant violation disclosure partly on this

basis. ${ }^{9}$ Our findings support this contention as a general explanation. While investors respond

negatively in the short term to debt covenant violation announcements (consistent with the earlier

research on short-term price effects), we also find equivalent patterns for investors' negative excess

return and net insider selling up to 12 months before a debt covenant violation disclosure and

investors' positive excess return and net insider buying up to 12 months after disclosure.

Second, given these patterns, we explore whether net insider trading around a debt covenant

violation disclosure leads or lags excess stock return. We find that insider trading leads excess stock

return in both the pre- and post-covenant disclosure periods by at least one month, although the post-

disclosure results are less significant. For the pre-covenant violation period, this suggests that insiders'

\footnotetext{
${ }^{9}$ We are not the first to explain this shift in insider selling to buying as a result of uncertainty resolution. Seyhun and Bradley (1997, p. 214) show a v-shaped response in insider trading and returns around a bankruptcy filing because "the market prices of these firms 'bottom out' after the announcement of the bankruptcy filing." Jiang and Zaman (2010) also point out that superior information about company cash flows (which can be significantly altered by debt renegotiations) is a powerful factor in explaining insider's transactions, relative to other explanations. Although we cannot rule out the possibility that insiders may also trade for liquidity reasons around a debt covenant violation dislclosure, it is unclear why liquidity trading would change significantly around a covenant violation disclosure in a way that would explain our results.
} 
trades may be driven by an information advantage unavailable to other market participants. We also find that the lead relation diminishes following adoption of the accelerated electronic filing rules for insider reporting under SOX (SEC 2002a, 2003). These results are robust to the presence of other public information around a covenant violation disclosure.

Third, we approximate the net gain to insiders' trades in months -12 to 12 around covenant violation disclosure month 0 based on cumulative excess stock return for different holding periods within the -12 to 12 interval. We calculate this net gain as the sum of the losses avoided by net insider selling for holding periods in pre-event months -12 to -2 and the gains to net insider buying for holding periods in post-event months 1 to 11 (section 3.6 explains the calculation in more detail). Our overall gain calculation, therefore, assumes that insiders both (a) sell before month 0 given foreknowledge of a possible covenant violation triggered by deteriorating prospects and (b) buy after month 0 given foreknowledge of the resolution of the debt covenant violation and improved prospects. We find that insiders gain abnormally in the pre- and post-periods combined by $\$ 1.965$ billion and $\$ 927$ million for assumed holding periods of up to 12 and up to 3 months following initial purchase or sale, respectively.

These results contribute to the literature on insider trading by documenting the behavior of and potential excess return to insiders around a debt covenant violation disclosure. Our results suggest that such excess return derives, in part, from insiders' superior insight about the process and outcome of debt and covenant renegotiation, and cannot be attributed to insiders' luck or ignorance on the part of outside investors and/or other public information. These results imply that public investors should pay more attention to insiders' buy and sell signals when companies renegotiate and resolve debt issues with their lenders, since companies typically disclose these outcomes in financial statements with 
delay, in contrast to insider filings, which investors must now file electronically within two days of the transaction (but without explanation of the reason for the transaction).

In terms of the prior research, our study relates to several strands in the literature. First, we extend Seyhun and Bradley (1997), who find that insiders tend to sell prior to and buy following a formal bankruptcy petition, and that such insider transactions precede both the pre- and post- market-reaction to a bankruptcy filing. Our findings indicate similar insider behavior, but in the context of a corporate news event far less threatening than bankruptcy, namely, a covenant violation disclosure, which seldom triggers insolvency. ${ }^{10}$

Second, our study relates to the empirical literature on the role of creditors in corporate governance and company decision-making built upon on early work by Dewatripont and Tirole (1994) among others. More recently, Nini et al (2009a, 2009b) and Roberts and Sufi (2009) document significant changes in operating, investing, and financing decisions before and after a debt covenant violation disclosure, suggesting that creditors play a critical role in improving company and share performance following a covenant violation. These studies do not examine the role of insiders surrounding a debt covenant violation disclosure, as we do here.

Third, our results are also consistent with studies that document that institutions trade on loan information allegedly obtained privately by those institutions as participants in loan renegotiations (Bushman et al. 2010, Ivashina and Sun 2010) and work in the developing field of forensic finance (Ritter 2008), founded on the idea that increased awareness of a questionable practice (in our case,

\footnotetext{
${ }^{10}$ Nini et al. (2009b) document that "the average covenant violator is far away from insolvency." (p. 14) See also note 1 for additional references on this point.
} 
insider trading around a debt covenant violation) may, in fact, curtail such behavior, which could then have implications for regulators.

Our paper continues as follows. Section 2 describes the data and sample. Section 3 explains the empirical methods and presents the results. Section 4 summarizes and concludes.

\section{Data and sample descriptive characteristics}

\subsection{Debt covenant violation sample}

SEC regulations and generally accepted accounting principles require the disclosure of all material breaches of debt covenants in the notes to the financial statements. ${ }^{11}$ As such, our first task is to identify a comprehensive sample of covenant violations in SEC filings. To cover disclosures over a recent period and consider the impact of possible temporal factors (e.g., a change in regulation), we gather data from January 1, 2000 to December 31, 2008. We use Direct Edgar to extract the SEC data and select first-time covenant violations only, as these should be more informative than others and restrict our sample to one violation per company, which increases the independence of the observations. This first step identifies 54,876 cases of potential covenant violation based on the following search terms: credit; notes, covenant, ratio, loan, debt, indenture, in violation, breach, breached, not in or out of compliance, non-compliance, failed, failure or fails to comply, and granted or received waiver. We then eliminate observations identified by the search terms but unrelated to a debt

\footnotetext{
${ }^{11}$ The applicable rules are SFAS No. 78 (1983), EITF 86-30 (1986), SAS No. 59 (1989), SEC Regulation S-X, and SEC Release 33-8400 (for 8-K filings). Regulation S-X, 210.4-08, for example, states that "any breach of covenant of $\mathrm{a}[\mathrm{n}]$....indenture or agreement, [where] default or breach existed at the date of the most recent balance sheet being filed and which has not been subsequently cured, shall be stated in the notes to the financial statements."
} 
covenant violation $(23,839)$, covenant violations relating non-compliance with environmental

employee, by-law, lease and marketplace regulations and financial institutions not in compliance with reserve requirements $(6,627)$, repeat violations $(14,008)$, and those whose registrant CIK number could not be matched with a CRSP or Compustat number $(8,621)$. This produces a sample of 1,781 first-time debt covenant violations over 2000-2008.

\subsection{Insider trading data}

The second step merges these 1,781 companies with Thomson-Reuters' data on insider trading ${ }^{12}$, with the added constraint that we restrict the covenent violation sample to disclosures on or before December 31, 2007-to examine excess return and insider trading following a debt covenant violation disclosure for up to 12 months. This produces a final sample of first-time bond covenant violations for 1,718 different companies for which we have 506,447 insider trading observations over January 1 , 2000 to December 31, 2008. Panel A of table 1 summarizes the sample selection process and the effects of the data constraints. Because the text form of disclosure is non-uniform across companies, we also manually read the 1,718 disclosures as a quality check. We classify each violation as relating to technical, debt service, or loan default factors and whether the lender granted a waiver or did not grant a waiver and/or other forebearance. We also classify the filing type as Form 10-K, 10-Q, or 8-K.

\footnotetext{
${ }^{12}$ According to http://www.dialog.com, Thomson-Reuters' offers the "world's most expansive collection of insider trading data, and covers equity and convertible trades by individuals and institutions who are classified by the US Securities and Exchange Commission (SEC) as "insiders." An insider is an officer, director, a person with a 'policy-making' role, or a beneficial owner (holder of $10 \%$ or more) of a company's stock. Insiders are both individuals and corporations, and are required by the SEC to report their direct and indirect holdings of the company's stock."
} 


\subsection{Sample descriptive characterstics}

Panel B of table 1 summarizes the number of trades and total insider shares traded by calendar year and by acquisition and disposition. This panel also reports an annualized buy-sell imbalance (BSI) ratio $\left[\left(\right.\right.$ buy $_{t}-$ sell $\left._{t}\right) \div\left(\right.$ buy $_{t}+$ sell $\left.\left._{t}\right)\right]$, where buy or sell $_{t}$ represents the number of trades $($ col. 4$)$ or total insider shares bought and sold in calendar year $\mathrm{t}(\mathrm{col} .7){ }^{13}$ This panel shows that over the study period the relative number of buy and sell trades for the sample as reflected in the BSI measure matches well with the number of buy and sell trades for all companies in the Thomson-Reuters sample (based on 3.3 million observations). On the other hand, the annualized BSI for total shares traded for the ThomsonReuters sample is less negative than the annualized BSI for total shares traded for the covenant violation sample. Insiders in covenant violation companies are, therefore, more likely to be net sellers in terms of the number of transactions, and, relative to the broader population, sell more shares than they buy per average transaction. These data reflect the deteriorating situation of these companies, about which insiders ostensibly should have better information relative to investors in general.

Panel $\mathrm{C}$ of table 1 describes the sample by key financial characteristics and compares these to the CRSP/Compustat population. We test for a non-zero difference in the covenant violation mean less the Compustat mean. As the table shows, relative to the broader population, covenant violation companies are smaller (log of total assets), report lower asset turnover (net sales to ending assets) and return on equity (net income to ending common equity), have higher bankruptcy risk (lower Altman Z score), and show lower ratios for short-term liquidity (current assets to current liabilities) and growth

\footnotetext{
${ }^{13}$ See section 3.1 for further discussion of BSI, including the merits of BSI calculated over intervals shortras an insider trading measure.
} 
opportunities (market-to-book value of common equity). The leverage ratio (total liabilities to total assets) is generally not different for the two groups. Observe, also, that more covenant violation disclosures occur in the early years (e.g., 47.6 percent of the filing dates occur in 2000 and 2001). This reflects two factors: first, the restriction that the sample contain only first-time covenant violation disclosures, including disclosures that might relate to a different debt issue by the same company and, second, the cyclical nature of covenant violation events, which are more prevalent in economic downturns. ${ }^{14}$ While a relaxation of this restriction would result in a more uniform distribution of events across time, a large majority of those later events would also likely signal less information to an investor or insider (and would be costly to gather as a data collection exercise). Our findings, hence, may not generalize to the larger set of all covenant disclosures. Panel $\mathrm{C}$ of table 1 also shows that covenant violation companies relative to the Compustat population have a Big 4 firm as auditor, and such Big 4 auditor is more likely to issue a qualified versus unqualified opinion. Panel C further shows that a high percentage of covenant violation disclosures report a waiver (granted by the lender) and that most violations (and waivers) are technical in nature, in contrast to a more severe debt service or loan default covenant violation.

Lastly, panel $\mathrm{C}$ reports the short-term market response around a debt covenant violation disclosure. While these results may be interesting in their own right, we report these results because the expectation of an announcement effect could be a pre-condition for an earlier trade by some insiders. We calculate the short-term response as the three-day cumulative mean excess stock return around the

\footnotetext{
${ }^{14}$ Nini et al. (2009b) report a similar trend, even though their covenant violation sample period covers 19962007.
} 
filing date based on a market model of daily returns (with a value-weighted market index). Panel C shows negative mean excess return for all years except filing date year 2004, and these are significantly negative for six (and for all years combined) based on a two-tailed $t$ test. Companies in the 25th percentile experience greater negative mean announcement effects, from -3.2 to -7.8 percent. These results, therefore, extend Beneish and Press (1995a, 1995b) by showing that investors recognize a covenant violation disclosure in an SEC filing as a significant adverse event for a more recent sample. Unreported tests also show that the negative market effect occurs regardless of SEC form type, although, as one would expect, a t test of difference in the mean excess return for each filing type reveals a significantly more negative mean three-day response for disclosures in 8-K filings (-3.94\%) versus $10-\mathrm{K}(-0.88 \%)$ or $10-\mathrm{Q}(-2.01 \%)$ filings. This confirms what prior research would predict, because companies and investors face a four-five day lag from SEC conform date to filing date for an 8-K report, whereas the conform date to filing date lag could be as high 45 days for a $10-\mathrm{Q}$ and up to 90 days for a 10-K. For the latter, much other information could have been disclosed in an earlier earnings release and/or as other information in the $10-\mathrm{K}$ or $10-\mathrm{Q}$ filing. On the other hand, an $8-\mathrm{K}$ report focuses one or a small number of news items only (Carter and Soo 1999). ${ }^{15}$

\footnotetext{
${ }^{15}$ Unreported analysis also shows significantly negative three-day cumulative mean excess return over filing date years 2000-2007 for each of the sub-samples of violation type (debt service, default, technical) and covenant action (waiver, non-waiver) and that the mean negative three-day cumulative excess return for non-waiver companies (-3.16\%) signficantly exceeds the mean three-day cumulative excess return for waiver companies $(-1.26 \%)$ based on a two-sample t test. Beneish and Press (1995a, 1995b) and Lan et al. (2010) report similar findings based on short-window excess return, also reflecting the general conclusion that investors interpret the combination of a covenant violation disclosure with a waiver as less severe than a covenant violation without a waiver. Unreported analysis also shows standardized daily unsigned excess return (as defined in Griffin 2003) as signficantly greater than one on filing date zero for each of the subsamples of violation type and covenant action and that standardized unsigned excess return for non-waiver companies exceeds that for waiver companies.
} 
To summarize, this section documents the following characteristics of our covenant violation sample. First, covenant violation companies differ (e.g, are smaller and less profitable) from the Compustat population and, second, the sample reflects greater numbers of observations in the earlier sample years, mostly because we examine first-time violations only. Both characteristics restrict our ability to generalize to the larger population of companies and to first-time and subsequent covenant disclosure companies. Third, even though covenant violation disclosures tend to be less obvious, less frequent, and less timely than regular and more publicized events such as earnings or dividends, we still find that investors consider such disclosures as newsworthy, with a negative short-term price effect. In other words, outside investors may lack insight about covenent issues during private debt renegotiations, but the same cannot be said about their initial response to disclosure, which is prompt, negative, and reasonably efficient. While not only a possible reason to trade, the finding that investors respond negatively to covenant violation disclosures also supports the view that such disclosures should be interesting (and potentially profitable) from an insider trading perspective. We now turn to the main results.

\section{Results}

\subsection{Insider trading around a debt covenant violation disclosure}

We conduct our insider trading tests as follows. First, based on the filing date of the covenant disclosure, we specify the calendar month of a debt covenent disclosure filing as covenant disclosure month 0 . For each covenant disclosure month, we then capture aggregate insider trading in month $t$ relative to covenant disclosure month 0 . For example, if the filing date were June 15, 2004, the filing month would be June 2004 (covenant disclosure month 0), and an insider trade transaction that takes 
place in the previous month, say, on May 20,2004, would be assigned to (along with all others in May 2004) to disclosure month -1 . In this way, we capture aggregate insider trading by acquisition and disposition for each company disclosure event in disclosure months $-t_{b}$ to $t_{e}$ relative to disclosure month 0 . While our data base reports insider trading by the number of trades, number of shares traded, and the price of shares traded, as discussed below, we focus on the number of shares traded in each covenant disclosure month $t_{b}=-12$ to $t_{\mathrm{e}}=12$ and calculate the cumulative buy-sell imbalance (BSI) ratio over these months as $\Sigma_{\mathrm{t}=-12, \ldots, \mathrm{T}}\left[\left(\right.\right.$ buy $_{\mathrm{qt}}-$ sell $\left._{\mathrm{qt}}\right) \div\left(\right.$ buy $_{\mathrm{qt}}+$ sell $\left.\left._{\mathrm{qt}}\right)\right]$, where buy $\mathrm{qt}_{\mathrm{qt}}$ or sell $\mathrm{qt}_{\mathrm{qt}}$ represents the mean number of shares, $\mathrm{q}$, purchased or sold in disclosure month $\mathrm{t}$ for companies with a covenant violation disclosure in month 0 . By definition, this measure ranges from -1 (no insider buying in disclosure month $\mathrm{t}$ ) to 1 (no insider selling in disclosure month $\mathrm{t}$ ).

Our review of prior research indicates BSI as a valid measure of the intensity of net insider trading for a company or portfolio of companies within an assumed interval (Lakonishok and Lee 2001, Atkas et al. 2008), with applications in other contexts, such as retail trading (Kumar and Lee 2006) and institutional trading (Lakonishok et al. 1992). Some other insider trading studies (Ke et al. 2003) scale the net number of insider buys and sells in an assumed interval (e.g., per quarter) by the number of common shares outstanding. While appropriate, this approach may skew the results to companies with fewer shares outstanding, which also tend to be smaller in size with less frequent insider trading (which could be more problematic using a monthly trading measure). Our BSI measure, based on the number of shares traded rather than a value of shares traded measure (as used in some studies), also avoids possible skewness because insider purchase transaction prices are generally lower than insider sale transaction prices. When the average price of an insider sale ( $\$ 21.88$ per share for our sample) exceeds 
the average price of a purchase ( $\$ 7.64$ per share for our sample), this difference makes BSI measure based on the value of shares traded more negative, which is compounded in a cumulative measure. ${ }^{16}$ Lastly, we calculate excess return for each company in the sample for 12 months before and after covenant violation month based on a market model of monthly excess return. We estimate the market model parameters over the prior 60 months of company return and use the CRSP value weighted index of market return. ${ }^{17}$

Table 2 and figure 1 present our initial results for the full sample, and for sub-samples of covenant waiver/non-waiver, technical violation, and pre-/post-accelerated filing, for cumulative mean BSI and cumulative mean excess return from covenant disclosure months -12 to $12 .{ }^{18}$ Our goal is to illustrate patterns in the data. First, regarding table 2, observe that cumulative BSI exhibits negative (positive) slope in months before (after) disclosure month 0 , and that this pattern persists for the sub-samples as well. For example, for the covenant waiver sample, cumulative BSI starts at 0.1534 , dips to -2.5766 for month 1 , and then reverts back to -0.9955 for month 12 (col. 4). Hence, insiders as a group, act as net sellers prior to month 1 and as net buyers after month 1 . Second, observe from table 2 that for all partitions except the post-acceleration filing sub-sample, the minumum cumulative excess return occurs on or around disclosure month 0 or 1 . For example, in the case of the covenant waiver sample,

\footnotetext{
${ }^{16} \mathrm{We}$ also checked and found that the difference in average trade price is not due to insider purchases at less than market prices due to insider compensatory arrangements.

${ }^{17}$ If 60 prior months were not available, we use the maximum number of observations up to 60 months. We also check and find qualitatively identical results using the CRSP equally-weighted return as the market index or based on market-adjusted returns, calculated as the difference between monthly stock return and a valueweighted or equally-weighted market index.

${ }^{18}$ Hereafter, we drop the word "mean" from the terms cumulative mean BSI and cumulative mean excess return, but do not change the calculation.
} 
cumulative excess return begins at -0.0101 , drops to -0.1393 for month 0 , and finishes at 0.0065 (col.

5). In other words, market-adjusted stock prices generally decline prior to covenant violation

disclosure month 0 or 1 and increase thereafter. ${ }^{19}$

At first glance, this suggests that insiders and outside investors might be responding to the same common information or, possibly, that outsiders might simply be mimicing the trades of insiders by tracking insider filings. Either way, such interpretation does not support the contention that insiders trade on superior debt renegotiation information not contemporaneously available to others. ${ }^{20}$

Closer inspection, however, reveals an alternative hypothesis, which figure 1 shows more clearly. For the full sample (figure 1, panel A), observe that cumulative BSI leads cumulative excess return both before and after covenant violation disclosure month 0 . For example, cumulative BSI turns up around month 1, whereas cumulative excess return turns up around month 4 . For the covenant waiver sample (figure 1, panel B), which reflects a less severe signal about the outcome of debt renegotiation, cumulative BSI even more clearly leads cumulative excess return before and after disclosure month 0 . Both graphs, therefore, raise the interesting and practical possibility that both insider selling and insider buying around a debt covenant violation disclosure might reveal important information about the direction of market excess return. Both graphs spotlight the hypothesis that insiders might trade on

\footnotetext{
${ }^{19}$ Our announcement tests also show significant negative excess return on annnouncement days -1 to 1 across all sample partitions.

${ }^{20}$ As a check on these results, we also examine insider trading based on random disclosure months. That is, we calculate cumulative BSI by assigning insider trading from a randomly-selected "psuedo" month from the study period to each of disclosure months -12 to 12 . Cumulative BSI based on psuedo months should not reflect the same behavior as net insider purchases and sales in the pre-covenant violation and post- covenant violation months. Untabulated analysis shows no pronounced positive or negative trend in cumulative BSI based on randomly-selected psuedo months.
} 
superior information about debt renegotiation, revealed publicly for the first time in an SEC disclosure filing, which in most cases companies reveal on a delayed basis, as a note in a $10-\mathrm{K}$ or $10-\mathrm{Q}$ filing. ${ }^{21}$

Next, we formally test the relation that BSI leads excess stock return.

\subsection{Regression tests of BSI as a leading indicator of excess stock return}

We test for a lead relation between excess stock return and BSI around a debt covenant violation disclosure by estimating the following time-series regression model over disclosure months -12 to 12 :

$$
\mathrm{ER}_{\mathrm{t}}=\alpha+\beta_{1} \mathrm{BSI}_{\mathrm{t}}+\beta_{2} \mathrm{BSI}_{\mathrm{t}-1}+\beta_{3} \mathrm{BSI}_{\mathrm{t}-2}+\varepsilon_{\mathrm{t}}
$$

where $\mathrm{ER}_{\mathrm{t}}=$ mean excess return over companies in the sample in month $\mathrm{t}$ based on the market model, BSI $_{t}=\left[\left(\right.\right.$ buy $_{t}-$ sell $\left._{t}\right) \div\left(\right.$ buy $_{t}+$ sell $\left.\left._{t}\right)\right]$, where buy ${ }_{t}$ or sell ${ }_{t}$ represents the mean number of buy and sell insider trades over companies in the sample in month $\mathrm{t}$, and $\varepsilon_{\mathrm{t}}$ equals random error. We use this model to test the null hypotheses that $\beta_{1}, \beta_{2}$, or $\beta_{3}=0$. ${ }^{22}$ For $\beta_{2}$ or $\beta_{3}$, we examine the alternative that the coefficient is significantly positive, which would indicate a significant association between BSI in months $\mathrm{t}-1$ or $\mathrm{t}-2$ and ER in month $\mathrm{t}$. Also, should we not reject the null hypotheses that $\beta_{1}=0$, this would suggest that such variable $\left(\mathrm{BSI}_{\mathrm{t}}\right)$ has no relation to $\mathrm{ER}$, incremental to BSI in the other months. ${ }^{23}$

We also expand model 1 to include the indicator variable Pre $=1$ for filings before the two-day

\footnotetext{
${ }^{21}$ These graphs also partially mirror Ke et al. (2003), who show a similar pattern in net insider selling and cumulative excess return in months -16 to -3 relative to disclosure month 0 , when a company breaks a prior string of quarterlty earnings increases by an earnings decrease, and use that graph to support their conclusion that "insiders possess, and trade upon, knowledge of specific and economically significant forthcoming accounting disclosures as long as 2 years prior to the disclosure.” (p. 315).

${ }^{22} \mathrm{We}$ also estimate models that include $\mathrm{BSI}_{\mathrm{t}+1}$, that is, a variable that tests whether BSI lags ER (see note 27)

${ }^{23}$ Seyhun and Bradley (1997) estimate a similar model where insider trading and excess stock return is aggregated quarterly and biannually, rather than monthly (as we examine in this study) and, thus, they examine the lead relation over a minumum of three months.
} 
accelerated electronic filing rule became effective (as of June 30, 2003), otherwise zero, and interact

this variable with $\mathrm{BSI}_{\mathrm{t}-1}$ to check for a change in the lead relation between $\mathrm{BSI}_{\mathrm{t}-1}$ and $\mathrm{ER}_{\mathrm{t}}$ following the SEC's accelerated filing rule. ${ }^{24}$ We state the expanded model as follows:

$$
\mathrm{ER}_{\mathrm{t}}=\alpha+\beta_{1} \mathrm{BSI}_{\mathrm{t}}+\beta_{2} \mathrm{BSI}_{\mathrm{t}-1}+\beta_{3} \mathrm{BSI}_{\mathrm{t}-2}+\beta_{4} \text { Pre }+\beta_{5} \mathrm{BSI}_{\mathrm{t}-1} \mathrm{x} \text { Pre }+\varepsilon_{\mathrm{t}}
$$

Table 3 presents the results for different partitions of the sample at three levels of aggregation: (1) observations for event months -12 to 12 pooled across all years ( 23 obs.), (2) observations for event months -12 to 12 pooled across each of the pre-accelerated and post-accelerated observations ( $46 \mathrm{obs}$.), and (3) observations for event months -12 to 12 for each of years 2000-2007 (184 obs.) stacked into a single regression. ${ }^{25}$ We show results for three levels of aggregation to check for possible trade-offs between bias from measurement error in BSI (since it is the independent variable in the regression) and parameter efficiency. As a check on the impact of market trends on the analysis, we also estimate models 1 and 2 by stacking disclosure months -12 to 12 in each of 2000-2007 (aggregation level 3) with the addition of a dummy variable for year $(2001, \ldots, 2006=1$, otherwise zero).

First, panel A of table 3 shows significantly positive coefficients for BSI $\mathrm{t}_{\mathrm{t}-1}$ and $\mathrm{BSI} \mathrm{t}_{\mathrm{t}-2}$ but not $\mathrm{BSI}_{\mathrm{t}}$ for most of the sample partitions, particularly those with the larger number of covenant disclosure

\footnotetext{
${ }^{24}$ A further possible expansion of models 1 and 2 would involve controlling for cross-sectional differences in the covenent violation sample, such as company differences. Unfortunately, given the nature of the covenant violation disclosure event, we have too few observations to conduct a pre- and post-disclosure time-series analysis where we analyze the observations at the company level. We do, however, examine the sensitivity of our results to company-based partitions of the data, for example, by high and low size (as proxied by market capitalization) and the information environment (as proxied by Big 4 or non-Big 4 auditor). See table 3.

${ }^{25}$ We exclude the 2008 monthly observations for BSI and ER from these regressions because of too few firsttime covenant violation disclosures in the prior year (6 per month on average).
} 
observations. ${ }^{26}$ This tests formally the relation suggested by figure 1 , and rejects the null hypothesis that the coefficients for $\mathrm{BSI}_{\mathrm{t}-1}$ and $\mathrm{BSI}_{\mathrm{t}-2}$ equal zero. Instead, we observe mostly significantly positive coefficients (and no significantly negative coefficients) for $\beta_{2}$. Thus, our analysis documents a significant association between excess return in month $\mathrm{t}$ and BSI one or two months earlier.

Panel B shows a similar pattern of significantly positive $\beta$ coefficients for $\mathrm{BSI}_{\mathrm{t}-1}$ and $\mathrm{BSI}_{\mathrm{t}-2}$ (and not significantly negative $\beta$ coefficients), except that larger sample size tends to drive the $\mathrm{BSI}_{\mathrm{t}-1}$ and $\mathrm{BSI}_{\mathrm{t}-2}$ coefficients closer to zero, consistent with an increase in measurement error as we base the larger number of monthly BSI observations on fewer covenant disclosures. Panel B also tests for a change in $\mathrm{BSI}_{\mathrm{t}-1}$ estimated over the pre- and post-accelerated filing observations. Estimated as separate regressions, the pre-accelerated filing $\mathrm{BSI}_{\mathrm{t}-1}$ coefficient $\left(\beta_{2}=0.0228\right)(\mathrm{col} .4)$ exceeds the postaccelerated filing $\mathrm{BSI}_{\mathrm{t}-1}$ coefficient $\left(\beta_{2}=0.0142\right)(\mathrm{col} .5)$. However, this difference is not significant in the combined regressions in panel $\mathrm{B}$, that is, the $\beta_{5}$ coefficients for $\mathrm{BSI}_{\mathrm{t}-1} \times$ Pre in the regressions in cols. 2,6 , and 8 are not significantly different from zero.

Panel C combines event months -12 to 12 for each of the years stacked into a single regression with 184 observations ( 23 monthly observations times 8 years). The first regression indicates a significantly positive coefficient for $\mathrm{BSI}_{\mathrm{t}-1}$ after controlling for differences in the regression intercept by year. In addition, the second regression reveals that the BSI coefficient in the pre-accelerated filing period is significantly larger than in the post-accelerated filing period. That is, the $\beta_{5}$ coefficient for

\footnotetext{
${ }^{26}$ Each panel also states the number of covenant violation disclosures as an indication of the number of disclosure observations in the pooling. For example, the 23 monthly time-series observations of the waiver group (col. 4) are based on a pooling of 1,266 covenant observations over 2000-2007.
} 
$\mathrm{BSI}_{\mathrm{t}-1} \mathrm{x}$ Pre in model 2 equals 0.0167 (col. 3), which is significantly different from zero. In other words, the Pre and Post regressions in panel $\mathrm{C}$ report similar $\beta_{2}$ coefficient signs in the pre and post regressions in panel $\mathrm{B}$, except that the larger number of observations in panel $\mathrm{C}$ for the same regression model, apparently, lowers the standard error of $\mathrm{BSI}_{\mathrm{t}-1} \mathrm{x}$ Pre, whose $\beta_{5}$ coefficient is significant in panel $\mathrm{C}$ (despite the effects of possible additional measurement error in the month-year observations). Panel $\mathrm{C}$ also reports results that exclude the 2007 excess return and BSI observations (cols. 4 and 7). These results are similar to the first regression (col. 2), which controls for year effects. Finally, as with the other panels, none of the $\beta_{2}$ coefficients in panel $\mathrm{C}$ for $\mathrm{BSI}_{\mathrm{t}-1}$ is significantly negative after controlling for year effects. ${ }^{27}$

We interpret these results to suggest that insiders' net trading behavior (as proxied by BSI) around a debt covenant violation disclosure leads market excess return by at least one month, although the results are less significant for post-covenant trading behavior. ${ }^{28}$ As such, we document statistically reliable evidence that insiders' actions reflect the use of superior information about covenant violation

\footnotetext{
${ }^{27}$ We observe a negative coefficient for $\beta_{1}$ in the post-acceleration period, which reflects a negative contemporaneous relation. While we do not test specific hypotheses about the sign of this coefficient, such finding is not inconsistent with the empirical literature (e.g., Atkas et al. 2008).

In addition to the regression results in table 3, untabulated analysis indicates no relation between ER in month $\mathrm{t}$ and BSI in month $\mathrm{t}+1$ (that is, prices lead insider trading), and we observe qualitatively similar results regardless of the calculation of excess return. Also, the possibility of excess return bias, which can be an issue in long-run cumulative return event studies (Mitchell and Stafford 2000), should be remote, in that there is no reason that such excess return bias should be of one sign prior to a covenant disclosure event and then switches after the event. We also test for differences in the coefficients for models 1 and 2 conditional on a 10-K or 10-Q filing, and find none. The sample size for $8-\mathrm{K}$ covenant disclosure filings is too small to allow for meaningful regression results.

${ }^{28}$ While after covenant disclosure, insiders and outsiders should have similar information about the covenant violation, insiders would still know more about the effects of creditor control rights, and how those rights might affect future profitability and liquidity, which outside investors may not reccive until the next financial report.
} 
as part of debt or covenant renegotiation. We contend this could occur because insiders can exploit the irregular and untimely nature of a covenant violation disclosure.

While these results may be new to the literature, they do not appear to be anomalous, however, in that we observe similar results in a formal bankruptcy setting (Seyhun and Bradley 1997) and in emerging work by Bushman et al. (2010) and Ivashina and Sun (2010), who suggest that institutions participating as fiduciaries in debt renegotiation may trade ahead of the market. This further means that we cannot, without additional analysis, characterize insiders' superior information as exclusively non-public and, hence, subject to insider trading enforcement. These results have additional implications for regulation in that the ability of insider trading to lead market excess return drops when we focus on insider trading after June 30,2003, at which time the SEC required insiders to report trades in an electronic filing within two days of the transaction. Finally, as a caveat, we acknowledge that this finding derives from a statistical relation, and so factors other than adoption of the SEC rule could also account for the change in relation, for example, greater awareness and openness generally about the merits of insider trade analysis from academic and industry research and heightened media scrutiny, and the sample distribution of covenant violation events, which favors the pre-acceleration period (table 1).

\subsection{Other information around a debt covenant violation disclosure}

While our finding of a v-shaped pattern of cumulative excess return around covenant violation disclosure month 0 seems robust in that Nini et al. (2009b, figure 8) and Lan et al. (2010, table 5) both confirm the fact of significant negative excess return prior to and significant positive excess return after a covenant violation disclosure, the leading indicator role of BSI could possibly be explained by 
information unrelated to bond or covenant renegotiation disclosures. As a further issue of robustness, we therefore consider whether the trend in excess return around a debt covenant violation disclosure more likely stems from non-public debt covenant information (potentially exploitable by insiders) or from elsewhere such as from publicly available reports. Should we find similar results for companies with low (versus high) public information availability, this increases the likelihood that the elevated insider trading documented in the previous section relates to private information obtained through bond or covenant renegotiations rather than some public source.

To implement this test, for each company in the covenant violation disclosure sample, we identify from Direct Edgar all 8-K reports filed by the company from 12 months before to 12 months after covenant violation disclosure date. This search produces 17,772 individual 8-Ks, excluding 8-Ks with a covenant violation disclosure. We then use Direct Edgar to list all the itemized disclosures in each 8$\mathrm{K}$ report. As per the 8-K filing instructions (SEC 2010), these range from item 1.01 (registrant's business and operations) to item 9.01 (financial statements and exhibits/press releases). This search produces 35,746 individual $8-\mathrm{K}$ items, excluding 8 -Ks with a covenant violation disclosure.

Next, we split the sample into two partitions of public information availability based on (a) information intensity and (b) information timing. First, we construct company-specific metrics of information flow around a covenant violation as the number of 8-K reports in each of months -12 to 12 around the month of a covenant violation disclosure (metric 1 ) or the number of $8-K$ items in the $8-\mathrm{K}$ 
reports in each of months -12 to 12 around the month of a covenant violation disclosure (metric 2 ). ${ }^{29}$ We also construct company-specific metrics 1 and 2 based on a subset of the 8 -K items, namely, item 2 (financial information), item 3 (securities and trading markets), and item 4 (matters related to accountants and financial statements) to reflect those $8-\mathrm{K}$ item disclosures that might relate more to debt contracts and debt renegotiation than others, although we acknowledge the subjective nature of this procedure. Second, we assign a company-specific metric into one of two groups, split on the basis of above or below the sample median. The first split is based on the number of $8-\mathrm{K}$ or $8-\mathrm{K}$ disclosure items (low 8-K intensity versus high 8-K intensity) in months -12 to 12 (8-K intensity). The second split is based on the proximity of the $8-\mathrm{K}$ filing date in months -12 to 0 relative to covenant violation month 0 (either late in months -12 to 0 or early in months -12 to 0 ) (8-K timing). Third, we examine whether the results in tables 2 and 3 differ on the basis of the two splits of other public information, namely, companies with low 8-K versus high 8-K intensity (partition 1) and companies with late 8-K versus early 8-K timing (partition 2).

For example, for companies with high 8-K intensity and, hence, presumably more public information, we expect the table 2 results to show diminished insider trading based on the reasonable assumption that insider managers would now have access to less non-public information about such companies. Similarly, we expect the table 2 results to show less insider trading when more $8-\mathrm{K}$

\footnotetext{
${ }^{29}$ The mean and standard deviation of the number of 8-Ks and 8-K items are remarkably stable over the pre- and post covenant violation disclosure months, with no elevated activity around month 0 . The mean and standard deviation of the number of $8-\mathrm{K}$ items per company per month are 2.011 and 0.908 , respectively.
} 
information arrives earlier than later in months -12 to 0 , again, assuming insider managers would now have access to less non-public information, and less time to exploit a possible price drop.

On the other hand, should the results in table 3 strengthen for covenant violation disclosures with high 8-K intensity, then we might attribute such insider trading more to other public information rather than non-public debt covenant information. In other words, the results would be driven more by public than private information. Contrariwise, should the table 3 results strengthen for covenant violation disclosures with early 8 -K disclosures in months -12 to 0 , then the results might also relate more to public information (in the early 8 -K disclosures) rather than non-public debt covenant information. We examine these possibilities to shed light on whether insiders' use of non-public information, rather than their use of public information, might explain better the insider trading relations in tables 2 and 3.

Table 4 presents the results for cumulative BSI and cumulative excess return split by 8 -K intensity and $8-\mathrm{K}$ timing (based on public information availability metric 2 ) ${ }^{30}$ We first observe that while cumulative BSI for high 8-K intensity companies declines more rapidly in months - 12 to 0 than low 8$\mathrm{K}$ intensity companies (cols. 2 and 3), it also increases more rapidly in months 1 to 12 . The mean BSI difference (col. 4) in months -12 to 12 and -12 to 0 , however, is not significant based on a two-sample t-test (e.g., two-tailed probability $=0.6863$ for the mean BSI difference in months -12 to 0 ). In other words, we observe a v-shaped pattern of cumulative BSI for both groups. This increases the likelihood that it is not the intensity of other public information that drives the insider trading results. We calculate mean BSI difference over -12 to 12 as low intensity BSI less high intensity BSI in months -12

\footnotetext{
${ }^{30}$ Untabulated analysis shows materially unchanged results for public information availability metric 1 and metrics 1 and 2 for a subset of the 8-K item disclosures (items 2, 3, and 4).
} 
to 0 (due to the expectation of more insider selling for low 8 -K intensity companies) and high intensity BSI less low intensity BSI in months 1 to 12 (due to the expectation of more insider buying for low 8$\mathrm{K}$ intensity companies). We also graph these results in figure 2. Panel A, for example, clearly shows similar patterns of BSI for low and high intensity companies.

Second, we run similar tests for cumulative BSI partitioned on early versus late 8-K timing. While cumulative BSI drops more rapidly for late than early 8-K filings in months -12 to 0 (cols. 5 and 6 )-as we would expect given a relative dearth of public information in the early period for late filers-both groups show a v-shaped pattern around month 0 . Also, while the mean BSI is generally more negative for late 8-K filers, the mean BSI difference (col. 7) is not significantly different from zero (e.g., twotailed probability $=0.2458$ for mean BSI difference in months -12 to 0 ).

Table 4 also reports cumulative excess return for the $8-\mathrm{K}$ intensity and $8-\mathrm{K}$ timing partitions. All four partitions show declining cumulative excess return in months -12 to 0 , and three of the four partitions show increasing cumulative excess return beginning around month 0 . The high 8 -K intensity sample, however, does not reflect the same V shape as the other partitions. Because this occurs only for the high $8-\mathrm{K}$ intensity sample, we reasonably attribute this to other public information, since that is the main difference between the two groups.

We also test whether mean monthly excess return differs by partition. Excess return is, indeed, more negative for high $8-\mathrm{K}$ intensity companies over -12 to $12(2$-tailed t test probability $=0.0063)$ and -12 to $0(2$-tailed t test probability $=0.0109)$, which is reasonable given the adverse situation of all covenant violation companies prior to month 0 , about which more is made public by a high $8-\mathrm{K}$ intensity company. We observe similar results when we partition on 8-K timing. Both groups' 
cumulative excess return reflects a V shape in months -12 to 12 . However, the mean monthly excess return difference is not significant. The mean monthly differences are positive, nonetheless, especially in months -12 to 0 , suggesting a stronger negative response for early $8-\mathrm{K}$ filers in that interval.

However, we still find a v-shaped response over months -12 to 12 for late 8-K filers, which we contend are the companies whose stock price is less driven by public information but, instead, by non-public information, possibly revealed publicly with delay, for example, as an insider trading filing or an SEC filing other than an $8-\mathrm{K}^{31}$ In sum, the results in table 4 suggest that the insider trading and excess stock patterns we observe in table 3 are not subsumed when challenged by the potential impact of other public information. We obtain similar results both when public information intensity is low and when investors receive such information later in the period ending with a debt covenant violation disclosure.

\subsection{Regression tests controlling for 8-K intensity and 8-K timing}

This section examines the relation between insider trading and excess stock return for each of the 8-K intensity and 8-K timing partitions. We first estimate time-series model 1 (section 3.2) for each of the partitions and then estimate two additional time series models, which include the $8-\mathrm{K}$ partition as a dummy variable that interacts with lagged $\mathrm{BSI}$, specifically $\mathrm{BSI}_{\mathrm{t}-1}$. We specify the general model as:

$$
\mathrm{ER}_{\mathrm{t}}=\alpha+\beta_{1} \mathrm{BSI}_{\mathrm{t}}+\beta_{2} \mathrm{BSI}_{\mathrm{t}-1}+\beta_{3} \mathrm{BSI}_{\mathrm{t}-2}+\beta_{4} \mathrm{Dum}+\beta_{5} \mathrm{BSI}_{\mathrm{t}-1} \mathrm{x} \text { Dum }+\varepsilon_{\mathrm{t}},
$$

where $\mathrm{ER}_{\mathrm{t}}$ and $\mathrm{BSI}_{\mathrm{t}}$ are defined in section 3.2, and Dum is a dummy variable defined as either (a)

Intens equals 1 for low 8-K intensity companies, 0 otherwise, or (b) Timg equals 1 for late $8-\mathrm{K}$ companies, 0 otherwise. With model 3, we test the significance of $\beta_{5}$, in other words, whether the $\beta_{5}$

\footnotetext{
${ }^{31}$ We have noted already that most covenant violation disclosures are, indeed, reported with delay, in either a 10$\mathrm{K}$ or 10-Q filing, rather than in an 8-K (table 1).
} 
coefficient varies on the basis of the dummy variable for information intensity or information timing.

If either the low $8-\mathrm{K}$ intensity variable or the late $8-\mathrm{K}$ information variable increases (or does not affect) the propensity of insiders to exploit non-public information, we should not observe a significantly negative coefficient for $\beta_{5}$.

Table 5 presents the results for the same three levels of aggregation as in table 3 . Panel A of table 5 summarizes model 1 based on event months -12 to 12 pooled across all years for each of the four partitions. We observe a positive coefficient for $\mathrm{BSI}_{\mathrm{t}-1}$ in all regressions, which is significant for the low 8-K intensity sample, consistent with BSI leading excess stock return by one month when there is less public information.

Panel B summarizes models 1 and 3, where we combine as a single time series the means of the high and low 8-K intensity partitions (regressions 1-4) and the early and late 8-K timing partitions (regressions 5-8). Panel B reports that the intensity partitions show a significantly positive coefficient for $\mathrm{BSI}_{\mathrm{t}-1}$. But whereas regressions 1-3 estimate model 1, regression 4 estimates model 3 with the interaction of $\mathrm{BSI}_{\mathrm{t}-1}$ and Intens (1 for low intensity, 0 for high intensity). Importantly, regression 4 shows significantly positive coefficients for both $\mathrm{BSI}_{\mathrm{t}-1}$ and $\mathrm{BSI}_{\mathrm{t}-1} \mathrm{x}$ Dum (Intens). In other words, $\mathrm{BSI}_{\mathrm{t}-1}$ leads excess stock return by one month more strongly for low $8-\mathrm{K}$ intensity companies than high 8-K intensity companies. As we suggested earlier, with less (more) public information (which we proxy by low information intensity), insiders should have a higher (lower) propensity to exploit nonpublic information, and this is what we find on the context of elevated non-public information around a covenant violation disclosure. On the other hand, regressions 5-7 (model 1) and 8 (model 3) in panel B show no clear evidence that the coefficient for $\mathrm{BSI}_{\mathrm{t}-1}$ differs on the basis of $8-\mathrm{K}$ timing. The 
coefficients for $\mathrm{BSI}_{\mathrm{t}-1}$ and $\mathrm{BSI}_{\mathrm{t}-1} \mathrm{x}$ Dum (Timg) are positive (as expected) but insignificant. None of the $\mathrm{BSI}_{\mathrm{t}-1}$ or interaction coefficients is significantly negative, however, which would refute our research expectations regarding the partitions.

Panel C summarizes the results where we pool the data each year. Similar to panel B, the interaction coefficient for $\mathrm{BSI}_{\mathrm{t}-1} \mathrm{x}$ Dum is positive and significant for 8-K intensity (regression 2) and positive and insignificant for 8 -K timing (regression 4). Thus, regardless of the level of aggregation for the time-series regressions, the lead relation between $\mathrm{BSI}_{\mathrm{t}-1}$ and $\mathrm{ER}_{\mathrm{t}}$ increases for companies with low public information (proxied by low 8-K intensity). Overall, these results support our contention that the propensity for insiders to exploit non-public information around a covenant violation disclosure drives the results in table 3. For if other public information were a material explanatory factor, our regressions would show negative coefficients for the dummy variables in regressions 3 and 4, which they do not.

\subsection{Financial Performance Around Debt Covenant Violation Disclosure Month 0}

To the extent that the benefits of creditors' control rights help explain our results regarding negative and positive excess return around a debt covenant violation disclosure, we should also observe equivalent shifts in the underlying financial statement variables that investors might use to assess stock return, particularly, measures of profitability and liquidity. Rather than rely on prior research, we provide direct evidence for this view by calculating the patterns of financial performance from four quarters before the month on covenant violation disclosure to four quarters after, where the covenant violation occurs in quarter -1. Building upon Nini et al. (2009b), we calculate ratios of profitability and growth (operating income to lagged total assets, interest expense to lagged total assets, market to 
book ratio), liquidity (cash and short-term securities to total assets, current ratio, leverage ratio), and balance sheet structure (log of total assets, leverage ratio, $\log$ of property, plant \& equipment).

Figure 3 graphs the results and shows that not only do profitability, growth prospects, and liquidity deteriorate in quarters -4 to -1 but they also improve in quarters 0 to 4 , consistent with a turn-around. In addition, companies reduce their investment in productive assets and finance with less debt in the quarters 0 to 4 following a debt covenant violation. Importantly, also, all the financial performance indicators begin to shift in the same quarter as the creditor intervention from the debt covenant violation. These trends support the view that the $\mathrm{V}$-shaped pattern of excess return reflects underlying measures about change in performance and financial structure stemming from debt renegotiation.

They are not intended, however, to explain insiders' possible use of non-public information about such measures (examined in sections 3.2 and 3.3) and whether such activities might be profitable (examined in the next section).

\subsection{Profitability of insider trades around a debt covenant violation disclosure}

Having established a statistically significant lead relation between insider trading and excess stock return, we now turn to a more practical issue, namely, the retrospective profitability of insider trading based on the indicator role of BSI. Prior research has used different approaches to estimate potential gains from insider trading. One approach tracks each insider's realized gain or loss from purchase and sale (or sale and repurchase). Unfortunately, our data set contains too few round trip transactions to make this viable. Instead, we examine insider trading based on two trading rules (trading rules 1 and 2), assumed the same for all investors. 
Under trading rule 1, we proxy the gain or loss to insiders assuming that insiders execute their trades in disclosure months -12 to 12 on the basis of the same investment horizon. Specifically, we assume an insider with superior information sells in one of disclosure months -12 to -2 and purchases in one of disclosure months 1 to 11 . We then derive the gain (loss) from insider activity as the combination of the net losses avoided over holding periods starting one month after selling (in months -12 to -2$)$ to disclosure month -1 and the net gains over holding periods starting one month after purchasing (in months 1 to 11 ) to disclosure month 12. We also calculate the dollar gain to each trade as the value of shares purchased or sold times the cumulative excess market return for each holding period starting one month after each insider transaction date. We ignore transaction costs.

Consider the following example of trading rule 1. Assume that Insider A sells 100 shares of Company $\mathrm{X}$ at $\$ 10$ per share on February 15,2004 , which is disclosure month -7 for a debt covenant violation disclosure regarding Company X, which is filed with the SEC on September 20, 2004 (month 0). Assume also that the market-adjusted stock price drops by five percent from March 2004 (month 6) to August 2004 (month -1). By selling on February 15, 2004, Insider A avoids a loss of $\$ 50$ (5\% x $100 \times \$ 10$ ). Our second trading rule (trading rule 2) assumes a shorter, three-month holding period. For example, if we assume a three percent market excess return for the period March 2004 (month -6) to May 2004 (month -4), then under trading rule 2 Insider A avoids a loss of \$30, which is less than the loss avoided under trading rule 1.

Table 6 summarizes the calculations for trading rules 1 and 2 and shows results that, in general, support our contention that insiders' gain from the use of superior information about a covenant violation as part of the debt renegotiation process. We draw five key observations from this table. 
First, based on a common trading rule, insider sellers avoid substantial losses in the pre-disclosure period, and insider buyers gain in the post-disclosure period, but less substantially. For example, under trading rule 1 (holding period up to 11 months), total losses avoided by insider sellers regarding predisclosure insider sales for all covenant violations amounts to $\$ 1.791$ billion (row 4 , col. 3 ), whereas insider buyers in the post-disclosure period gain by only $\$ 174$ million (row 3, col. 6), for a total of $\$ 1.965$ billion. Second, these insider gains and losses increase in the length of the assumed insider holding period. For example, the losses avoided from pre-disclosure insider sales for all covenant violations total \$946.8 million (row 4, col. 9) under a three-month trading rule (trading rule 2) versus $\$ 1.791$ billion under trading rule 1. Third, the results strengthen for larger companies and those with a Big 4 auditor, which is likely a reflection of both the larger sample size and the higher quality and/or importance of disclosures in general made by larger companies and Big 4 audited companies. This result is also consistent with Huddart and Ke (2007), who find that insiders sell less stock as information asymmetry increases. Fourth, both pre-disclosure losses and post-disclosure gains increase in magnitude for the covenant waiver sub-sample. This supports our expectation that a covenant waiver disclosure signals less uncertainty and a brighter future about the company's debt situation relative to a company not granted a waiver. In addition, while insider sellers of companies with a covenant violation and no waiver avoid substantial losses in the pre-disclosure period of $\$ 686.5$ million (row 19, col. 3), insider purchasers also lose $\$ 212.5$ million in the post disclosure period when no waiver occurs (row 18, col. 6). Fifth, we observe consistently negative pre-disclosure losses avoided from insider selling in all years except 2004, whereas the post-disclosure gains from insider buying are positive in four of the eight years only. 
In short, table 6 shows results that support our contention that insiders' sales and purchases around a debt covenant violation disclosure reflect their use of superior information. For if that were not the case, the gains and losses from buying and selling in both the pre- and post-disclosure periods would be similar, which they are not. Our analysis also offers an economically significant finding about the magnitude of losses avoided due to pre-disclosure insider selling, which we estimate as $\$ 1.791$ billion over the study period. Such losses avoided by insider sellers are also losses passed on to other investors, who doubtless would trade differently conditional on the same information advantages as insiders. We surmise that regulators and stock exchange officials, whose task it is to monitor and enforce insider trading rules, should find these results pertaining to insiders' dollar returns both practically and economically interesting.

\section{Summary and conclusions}

This study extends the literature on insider trading and creditor control rights by documenting significant gains to insiders up to 12 months before and after a first-time covenant violation disclosure in an SEC filing. Our specific context is important from a research and regulatory standpoint because, unlike the emphasis of the earlier studies on insider trading around prominent events, a first-time covenant violation disclosure is typically an infrequent, obscure, and untimely event, and not an obvious candidate for study or enforcement. Yet we find substantial pre-disclosure trading gains. In particular, our results suggest that insiders benefit by selling shares before a covenant disclosure (to avoid the loss from a price decline) and benefit further by purchasing shares after such disclosure, although the gains from the former activity exceed those from the latter. 
Our results suggest that insiders base their trades on an information advantage, derived from access to debt or covenant renegotiations, in that a regression analysis suggests that insiders may gain by selling at least one month prior to a pre-disclosure drop in market-adjusted stock price and by buying at least one month prior to a post-disclosure stock price increase.

Our results are also economically significant. For the covenant violation disclosures we study, we estimate that aggregate insiders' gains (the sum of losses avoided from pre-disclosure selling and gains to post-disclosure buying) approach almost two billion dollars over the eight year study period. Such insiders' gains can be expected to arise at the expense of those without access to the superior information. Although we cannot rule out the possibility that other informed investors (e.g., institutions) may have similar superior information, we contend the such information advantage is conferred on insiders rather than outside parties because of the nature of the covenant event itself. Investors are generally not privy to the debt or covenant renegotiation process and so cannot know about or anticipate a debt covenant violation disclosure. However, investors do respond negatively and significantly on the day of a covenant violation announcement, making it unlikely that insiders' gains would derive from the ignorance of outside investors. Moreover, outside investors who might have confidential access, for example, as members of creditors' committees, typically sign confidentiality agreements and accept restrictions on trading in any of the borrower's securities and, thus, despite motive would have limited opportunity to exploit their knowledge of the debt renegotiation until covenant issues are resolved and disclosed.

We also find that the ability of insiders' trades to lead the market diminishes after the adoption of accelerated electronic insider filing rules in 2003. This supports the view that investors' and other 
intermediaries' more timely access to insider filing information may have induced them to pay greater attention to understanding why insiders might be trading in the absence of disclosure of material information about company profitability and financial position, as required by securities law, although other factors correlated with the timing of the SEC regulation might also explain this result.

Finally, our results have implications for insiders, investors, and regulators. Because of the relative infrequency of a new covenant violation disclosure, and the lack of clear relation between an insider trade and the disclosure event, insiders face few obstacles from the standpoint of company and regulatory policy. The low cost of jeopardy for such trades is perhaps why we observe such elevated insider activity, especially net insider selling prior to covenant violation disclosure. Regulators might, therefore, consider extending their current focus on insider trading around major and regular events to other kinds of disclosures, although such focus would raise additional challenges for enforcement. For instance, a successful insider trading action by the SEC typically requires the agency to show that the insider had possession of specific material non-public information at the time of the trade (Veliotis 2010). But this would be difficult to establish in the context of a debt covenant violation disclosure because of an arguably tenuous link between the later unfavorable announcement effect and the basis or cause of the earlier insider transaction. 


\section{References}

Atkas, N., Bodt, E., and Oppens, H. (2008). Legal insider trading and market efficiency. Journal of Banking and Finance, 32(7), 1379-1392.

Beneish, M., and Press, E. (1993). Costs of technical violation of accounting-based debt covenants. Accounting Review, 68(2), 233-257.

Beneish, M., and Press, E. (1995a). The resolution of technical default. The Accounting Review, 70(2), 337-353.

Beneish, M., and Press, E. (1995b). Interrelation among events of default. Contemporary Accounting Research, 12(1), 57-84.

Beneish, M., Press, E., and Vargus, M. (2001). The relation between incentives to avoid debt-covenant default and insider trading. Working paper, April 23. Available at SSRN: http://papers.ssrn.com/ sol3/papers.cfm?abstract_id=268548.

Bushman, R., Smith, A., and Wittenberg-Moerman, R. (2010). Price discovery and dissemination of private information by loan syndicate participants. Journal of Accounting Research, no. doi: 10.1111/j.1475-679X.2010.00384.x.

Carter, M., and Soo, B. (1999). The relevance of Form 8-K reports. Journal of Accounting Research, $37(1), 119-132$.

Datta, S., and Iskandar-Datta, M. (1996). Does insider trading have information content for the bond market? Journal of Banking and Finance, 20(3), 555-575.

Demiroglu, C., and James, C. (2010). The information content of bank loan covenants. Review of Financial Studies, 23(10), 3700-3737.

Dewatripont, M., and Tirole, J. (1994). A theory of debt and equity: Diversity of securities and manager-shareholder congruence, Quarterly Journal of Economics, 109(4), 1027-54.

Dichev, I. and Skinner, D. (2002). Large-sample evidence on the debt covenant hypothesis, Journal of Accounting Research, 40(4), 1091-1123.

Elliot, J., Morse, D., and Richardson, G. (1984). The association between insider trading and information announcements, Rand Journal of Economics, 15(4), 521-536.

Financial Accounting Standards Board. (1983). Financial Accounting Standard No. 78. Classification of Obligations That Are Callable by the Creditor: An amendment of ARB No. 43. Chapter 3A. Stamford CT: FASB.

Financial Accounting Standards Board. Emerging Issues Task Force. (1986). Classification of Obligations When a Violation is Waived by the Creditor. Stamford CT: FASB

Garfinkel, J. (1997). New evidence on the effects of federal regulations on insider trading: The Insider trading and securities fraud enforcement act (ITSFEA). Journal of Corporate Finance, 3(2), 89111. 
Givoly, D., and Palmon, D. (1985). Insider trading and the exploitation of inside Information: Some empirical evidence. Journal of Business, 58(1), 69-87.

Gopalakrishnan, V., and Parkash, M. (1995). Borrower and lender perceptions of accounting information in corporate lending agreements. Accounting Horizons, 9(1), 13-26.

Griffin, P., and Grundfest, J. (2002). When does insider selling support a strong inference of fraud? Asia-Pacific Journal of Accounting and Economics, 9(2), 159-207.

Griffin, P. (2003). Got information? Investor response to Form 10-K and Form 10-Q EDGAR filings. Review of Accounting Studies 8(4): 433-460.

Hsieh, J., Ng, L., and Wang, Q. (2005). Analysts' recommendations and insider trading. Working paper, George Mason University, February 4.

Huddart, S., and Ke, B. (2007). Information asymmetry and cross-sectional determinants of insider trading. Contemporary Accounting Research, 24(1), 195-232.

Huddart, S., Ke, B., and Shi, C. (2007). Jeopardy, non-public information, and insider trading around SEC 10-K and 10-Q filings. Journal of Accounting and Economics, 43(1), 3-36.

Ivashina, V., and Sun, Z. (2010). Institutional stock trading and loan market information. Working paper, Harvard Business School, January.

Jagolinzer, A., and Roulstone, D. (2008). Litigation risk and the distribution of insiders' trades around earnings announcements, Chicago Booth Research Paper.

Jiang, X., and Zaman, M. (2010). Aggregate insider trading: Contrarian beliefs or superior information? Journal of Banking and Finance, 34(6), 1225-1236.

John, K., and Lang, L. (1991). Strategic insider trading around dividend announcements: Theory and evidence. The Journal of Finance, 46(4), 1361-1389.

Karpoff, J., and Lee, D. (1991). Insider trading before new issue announcements. Financial Management, 20 (Spring), 18-26.

Ke, B., Huddart, S., and Petroni, K. (2003). What insiders know about future earnings and how they use it: Evidence from insider trades. Journal of Accounting and Economics, 35(3), 315-346.

Kolasinski, A., and Li, X. (2010). Are corporate managers savvy about their stock price? Evidence from insider trading after earnings announcements. Journal of Accounting and Public Policy, 29(1), 2744.

Kumar, A., and Lee, C. (2006). Retail investor sentiment and return comovements. The Journal of Finance, 61(5), 2451-2486.

Lakonishok, J., Shleifer, A., and Vishny, R. (1992). The impact of institutional trading on stock prices, Journal of Financial Economics, 32(1), 23-43.

Lakonishok, J., and Lee, I. (2001). Are insiders' trades informative? Review of Financial Studies, 14(1), 79-111.

Lan, L., Ho, Y., and Premaratne, H. (2010). Creditor Control Rights, Loan Enforcement and Bankruptcy 
Regimes. Working paper, National University of Singapore, July 15. Available at SSRN: http://ssrn.com/abstract=1640422.

Lee, D., Mikkelson, W., and Partch, M. (1992). Managers' trading around stock repurchases. The Journal of Finance, 47(5), 1947-1961.

Louis, H., Sun, A., and White, H. (2010). Insider trading after repurchase tender offer announcements: Timing versus informed trading. Financial Management, 39(1), 301-322.

Lustgarten, S., and Mande, V. (1995). Financial analysts' earnings forecasts and insider trading. Journal of Accounting and Public Policy, 14(3), 233-261.

Marin, J., and Olivier, J. (2008). The dog that did not bark: Insider trading and crashes. The Journal of Finance, 63(5), 2429-2476.

Mitchell, M., and Stafford, E. (2000). Managerial decisions and long-term stock price performance. Journal of Business, 73(3), 287-329.

Nini, G., Smith, D., and Sufi, A. (2009a). Creditor control rights and firm investment policy, Journal of Financial Economics, 92(3), 400-420.

Nini, G., Smith, D., and Sufi, A. (2009b). Creditor control rights, corporate governance, and firm value. Working paper, University of Chicago, July 2. EFA 2009 Bergen Meetings Paper. Available at SSRN: http://ssrn.com/abstract=1344302.

Park, S., Jang, H., and Loeb, M. (1995). Insider trading activity surrounding annual earnings announcements. Journal of Business Finance and Accounting, 22(4), 587-614.

Penman, S. (1982). Insider trading and the dissemination of firms' forecasts. The Journal of Business, 55(4), 479-503.

Piotroski, J. and Roulstone, D. (2005). Do insider trades reflect both contrarian beliefs and superior knowledge about future cash flow realizations? Journal of Accounting and Economics, 39(1), 55-81.

Ritter, J. (2008). Forensic finance. Journal of Economic Perspectives, 22(3), 127-147.

Roberts, M., and Sufi, A. (2009). Control rights and capital structure: An empirical investigation. Journal of Finance, 64(4), 1657-1695.

Securities and Exchange Commission. (1934). Regulation S-X, 17 CFR, part 210, Form and content of and requirements for financial statements. SEC: Washington D.C.

Securities and Exchange Commission. (2002a). Final Rule: Ownership Reports and Trading by Officers, Directors and Principal Security Holders. 17 CFR Parts 240, 249, and 274. SEC: Washington D.C. August 29.

Securities and Exchange Commission. (2002b). File Rule: Release No. 33-8128 Acceleration of Periodic Report Filing Dates and Disclosure Concerning Website Access to Reports. 17 CFR Parts 210, 229, 240, and 249. SEC: Washington D.C. August 27. 
Securities and Exchange Commission. (2003). Final Rule: Mandated Electronic Filing and Website Posting for Forms 3, 4 and 5. 17 CFR Parts 230, 232, 239, 240, 249, 250, 259, 260, 269 and 274. SEC: Washington D.C. June 30.

Securities and Exchange Commission. (2004). Release No. 33-8400, 69 Federal Register 15593, SEC: Washington D.C. March 25.

Securities and Exchange Commission. (2010). Form 8-K Filing Instructions, OMB Number: 3235-0060, SEC: Washington D.C., 1-22.

Seyhun, H. (1986). Insiders' profits, costs of trading, and market efficiency. Journal of Financial Economics, 16(2), 189-212.

Seyhun, H. (1988). The information content of aggregate insider trading. The Journal of Business, 61(1), $1-24$.

Seyhun, H. (1990). Do bidder managers knowingly pay too much for target firms? The Journal of Business, 63(4), 439-463.

Seyhun, H., and Bradley, M. (1997). Corporate bankruptcy and insider trading. The Journal of Business, $70(2), 189-216$.

Siegel, G., and Hall, D. (2008). Confidentiality and disclosure in distressed investing. Review of Banking and Financial Services, 24(1), 1-10.

Sweeney, A. (1994). Debt-covenant violations and managers' accounting responses. Journal of Accounting and Economics, 17(3), 281-308.

Udpa, S. (1996). Insider trading and the information content of earnings. Business Finance and Accounting, 23(8), 1069-1095.

Veliotis, S. (2010). Rule 10b5-1 trading plans and insiders' incentive to misrepresent. American Business Law Journal, 47(2), 313-359. 
Figure 1: Cumulative Buy-Sell Imbalance Ratio ${ }^{1}$ and Cumulative Excess Return ${ }^{2}$ Around Debt Covenant Violation Disclosure Month 0

Panel A: All observations $(1,610)$

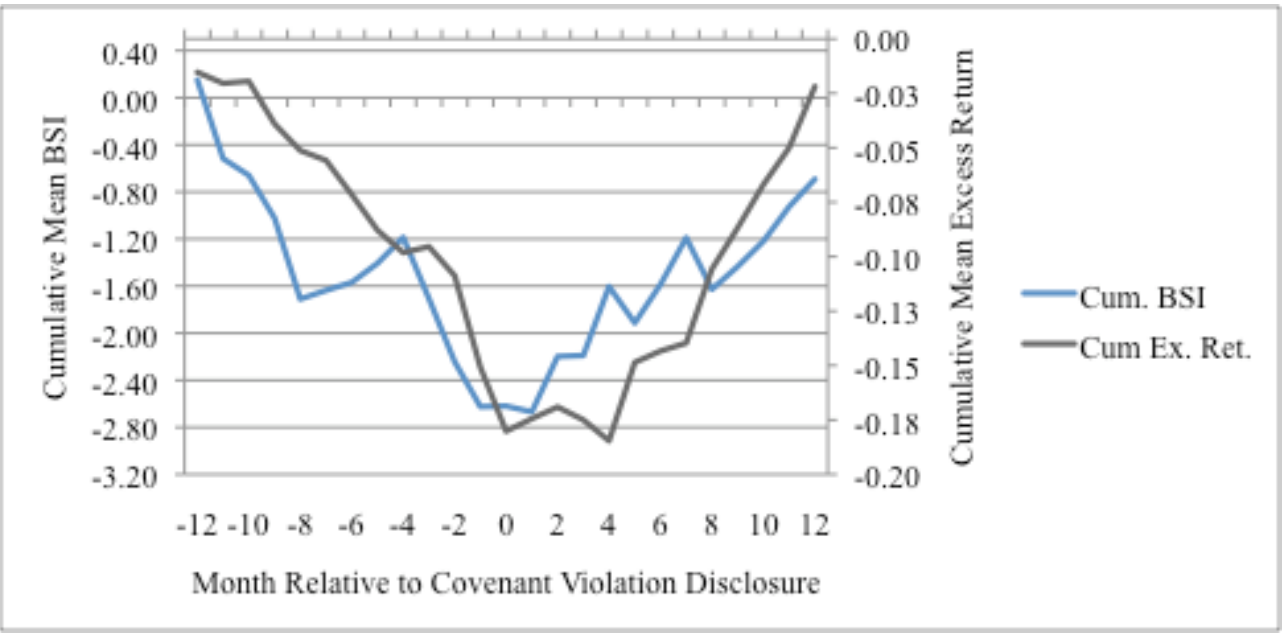

Panel B: Covenant waiver observations $(1,266)$

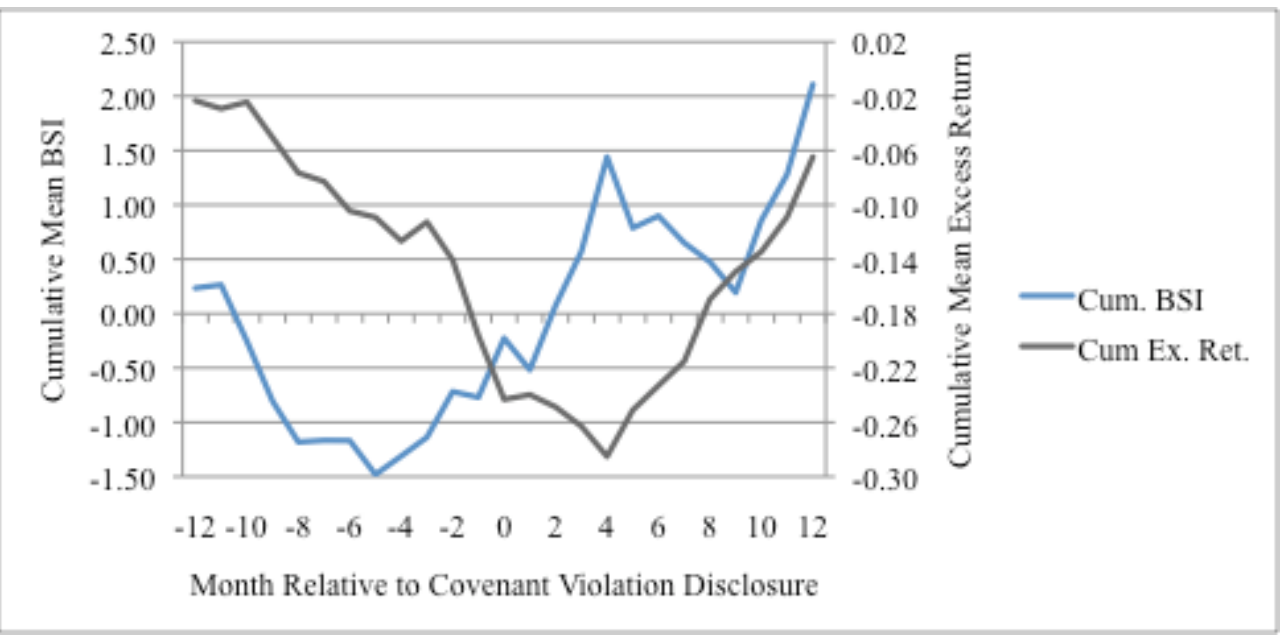

Notes to figure 1.

1. Cumulative buy-sell imbalance ratio equals $\Sigma_{\mathrm{t}=-12, \ldots, \mathrm{T}}\left[\left(\right.\right.$ buy $_{\mathrm{qt}}-$ sell $\left._{\mathrm{qt}}\right) \div\left(\right.$ buy $\left.\left._{\mathrm{qt}}+\operatorname{sel}_{\mathrm{q}}\right)\right]$, where buy $\mathrm{qt}_{\mathrm{qt}}$ or sell $\mathrm{q}_{\mathrm{qt}}$ represents the mean across q observations of insider shares traded for sample companies in disclosure month $t$.

2. Cumulative excess return equals the cumulative mean excess return over companies in the sample starting at month -12 , where excess return is based on the market model, and where the market model parameters are calculated over the prior 60 months. 
Figure 2: Cumulative Buy-Sell Imbalance Ratio ${ }^{1}$ and Cumulative Excess Return ${ }^{2}$ Around Debt Covenant Violation Disclosure Month 0: By 8-K Intensity ${ }^{3}$ and 8-K Timing ${ }^{4}$

Panel A: Cumulative Buy-Sell Imbalance Ratio
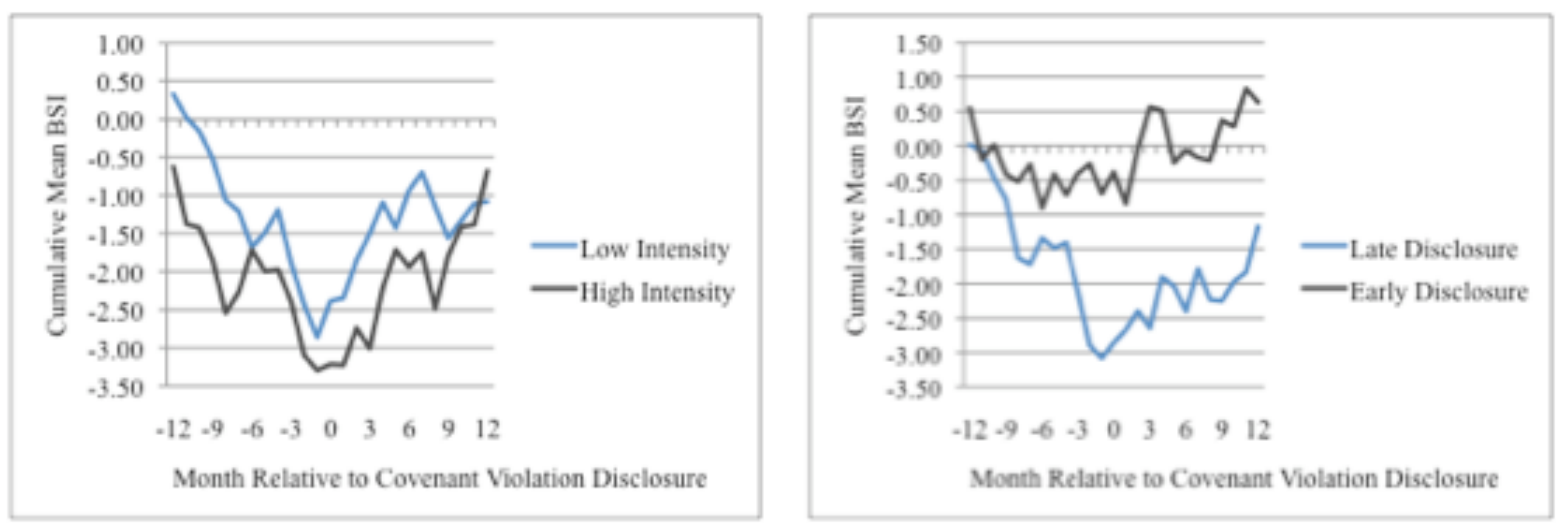

Panel B: By Cumulative Excess Return
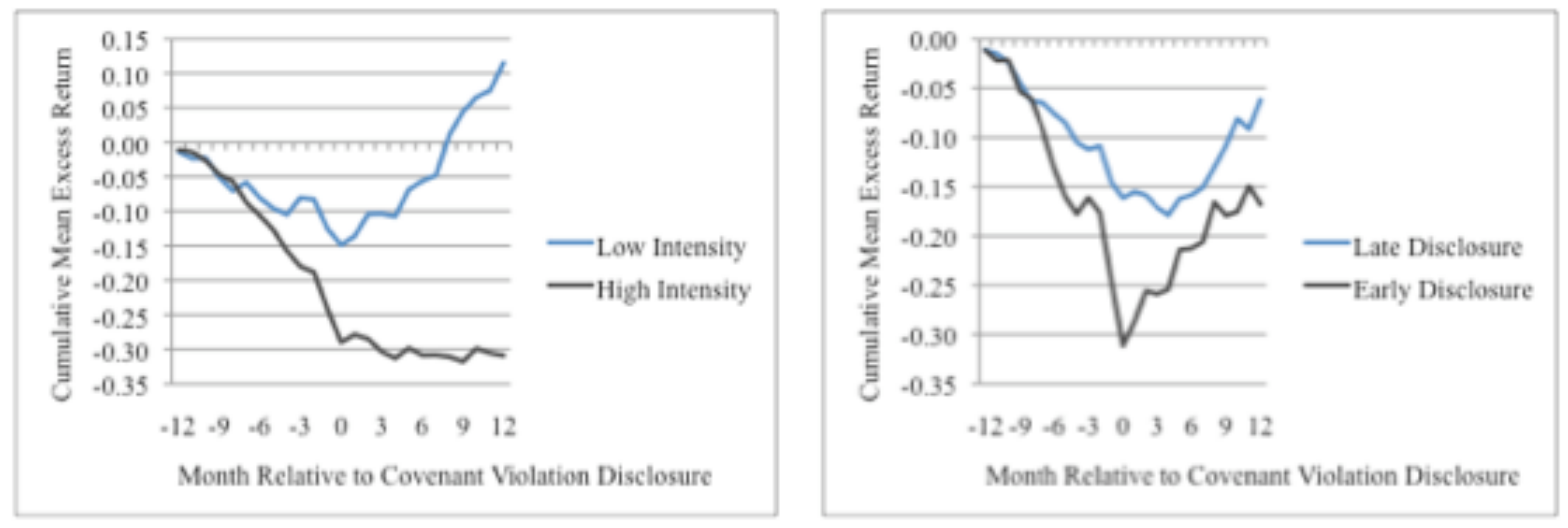

Notes to figure 2 .

1. Cumulative buy-sell imbalance ratio equals $\Sigma_{\mathrm{t}=-12, \ldots, \mathrm{T}}\left[\left(\right.\right.$ buy $\left._{\mathrm{qt}}-\operatorname{sell}_{\mathrm{qt}}\right) \div\left(\right.$ buy $\left.\left._{\mathrm{qt}}+\mathrm{sell}_{\mathrm{qt}}\right)\right]$, where buy $\mathrm{qu}_{\mathrm{qt}}$ or sell $\mathrm{qt}_{\mathrm{qt}}$ represents the mean across q observations of insider shares traded for sample companies in disclosure month $t$.

2. Cumulative excess return equals the cumulative mean excess return over companies in the sample starting at month -12 , where excess return is based on the market model, and where the market model parameters are calculated over the prior 60 months.

3. 8 -K intensity (high or low) defined relative to the median number $8-\mathrm{K}$ disclosure items.

4. 8 -K Timing (early or late) defined in terms of the proximity of the 8 -K filing date in months -12 to 0 to covenant violation month 0 . Early or late defined relative to the median $8-\mathrm{K}$ filing date in months -12 to 0 . 
Figure 3: Financial Performance ${ }^{1}$ Around Debt Covenant Violation Disclosure Month $0^{2}$
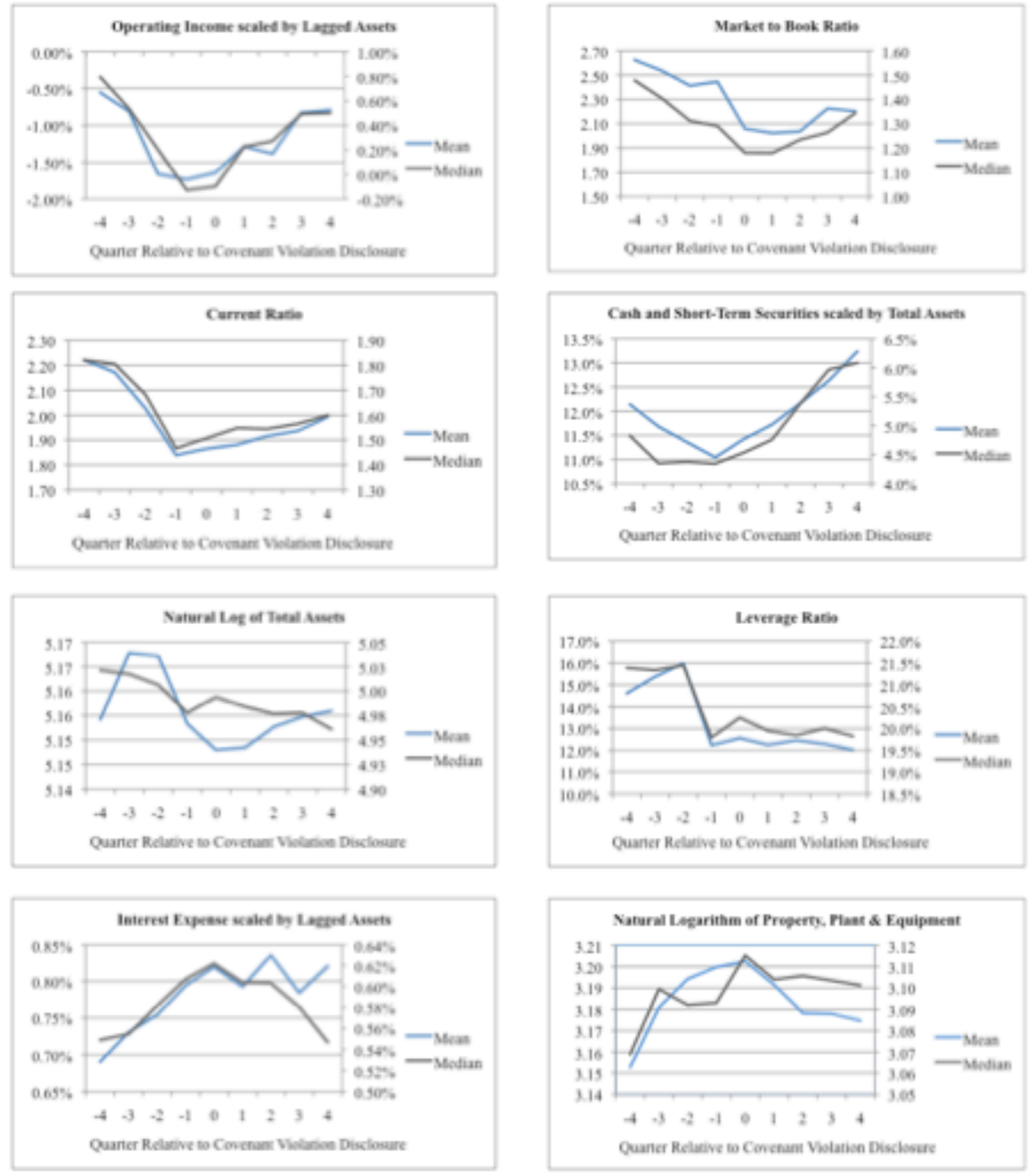

Notes to figure 3.

1. Variable definitions from Compustat: Operating income (oiadp), interest expense (xint), total assets (at), net worth $(s e q)$, cash and short-term securities (che), leverage $=$ long-term debt $(d l t t)$ to total assets $(a t)$, current ratio $=$ current assets $(a c t)$ to current liabilities $(l c t)$, property, plant \& equipment (ppent).

2. Covenent violation month zero occurs in quarter -1 . 
Table 1: Sample selection and characteristics

Panel A: Debt Covenant Violation Sample Selection

\begin{tabular}{|c|c|c|c|c|}
\hline Direct Edgar key term search terms and SEC filing & $10-\mathrm{K}$ & $10-\mathrm{Q}$ & $8-\mathrm{K}$ & All \\
\hline Initial sample & & & & 54,876 \\
\hline CIK could not be matched to CRSP or Compustat & & & & $(8,621)$ \\
\hline Non-debt related violation $^{1}$ & & & & $(6,627)$ \\
\hline Identified but unrelated to a debt covenant violation ${ }^{2}$ & & & & $(23,839)$ \\
\hline Repeat violation $^{3}$ & & & & $(14,008)$ \\
\hline Covenant disclosures 2000-2008 & & & & 1,781 \\
\hline Covenant disclosures 2008 & & & & (63) \\
\hline Final sample & & & & 1,718 \\
\hline \multicolumn{5}{|l|}{ Violation type frequency } \\
\hline Debt service violation & 5 & 3 & 7 & 15 \\
\hline Disclosure default & 10 & 2 & 28 & 40 \\
\hline Technical violation & 705 & 894 & 52 & 1,651 \\
\hline Undisclosed violation & - & - & 12 & 12 \\
\hline All & 720 & 899 & 99 & 1,718 \\
\hline \multicolumn{5}{|l|}{ Waiver and non-waiver frequency } \\
\hline Number of companies not granted a waiver & 108 & 188 & 71 & 367 \\
\hline Number of companies granted a waiver & 612 & 711 & 28 & 1351 \\
\hline All & 720 & 899 & 99 & 1718 \\
\hline
\end{tabular}

Panel B: Insider Trading By Year

\begin{tabular}{|c|c|c|c|c|c|c|}
\hline & Acquisition & Disposition & & Acquisition & Disposition & \\
\hline Year & No. trades & No. trades & $\mathrm{BSI}^{4}$ & $\begin{array}{c}\text { Total shares, in } \\
000 \mathrm{~s}\end{array}$ & $\begin{array}{c}\text { Total shares, in } \\
000 \mathrm{~s}\end{array}$ & $\mathrm{BSI}^{4}$ \\
\hline \multicolumn{7}{|c|}{ Panel A: Debt Covenant Violation Sample } \\
\hline 2000 & 13,408 & 21,199 & $-22.51 \%$ & 402,094 & 550,982 & $-15.62 \%$ \\
\hline 2001 & 10,756 & 19,459 & $-28.80 \%$ & 385,041 & 585,191 & $-20.63 \%$ \\
\hline 2002 & 11,993 & 23,080 & $-31.61 \%$ & 315,649 & 521,335 & $-24.57 \%$ \\
\hline 2003 & 11,679 & 55,692 & $-65.33 \%$ & 535,129 & $1,680,291$ & $-51.69 \%$ \\
\hline 2004 & 12,197 & 73,116 & $-71.41 \%$ & 296,728 & $1,584,549$ & $-68.45 \%$ \\
\hline 2005 & 14,192 & 70,590 & $-66.52 \%$ & 319,431 & $1,222,412$ & $-58.57 \%$ \\
\hline 2006 & 12,543 & 70,832 & $-69.91 \%$ & 372,706 & $1,139,805$ & $-50.72 \%$ \\
\hline 2007 & 15,765 & 35,317 & $-38.28 \%$ & 807,241 & 600,989 & $14.65 \%$ \\
\hline 2008 & 18,749 & 15,880 & $8.28 \%$ & 495,367 & 281,007 & $27.61 \%$ \\
\hline \multicolumn{7}{|c|}{ Panel B: Thomson-Reuters Sample } \\
\hline 2000 & 70,792 & 119,501 & $-25.60 \%$ & $3,440,621$ & $4,594,493$ & $-14.36 \%$ \\
\hline 2001 & 54,802 & 123,800 & $-38.63 \%$ & $3,921,536$ & $5,870,490$ & $-19.90 \%$ \\
\hline 2002 & 66,922 & 119,396 & $-28.16 \%$ & $4,228,812$ & $4,812,623$ & $-6.46 \%$ \\
\hline 2003 & 58,193 & 306,167 & $-68.06 \%$ & $4,340,311$ & $11,383,670$ & $-44.79 \%$ \\
\hline 2004 & 76,357 & 466,559 & $-71.87 \%$ & $14,803,728$ & $15,641,549$ & $-2.75 \%$ \\
\hline 2005 & 84,973 & 513,038 & $-71.58 \%$ & $7,343,013$ & $14,390,412$ & $-32.43 \%$ \\
\hline 2006 & 75,142 & 509,802 & $-74.31 \%$ & $6,571,720$ & $11,059,202$ & $-25.45 \%$ \\
\hline 2007 & 102,797 & 250,702 & $-41.84 \%$ & $10,581,832$ & $4,865,195$ & $37.01 \%$ \\
\hline 2008 & 119,334 & 113,381 & $2.56 \%$ & $8,834,551$ & $2,119,578$ & $61.30 \%$ \\
\hline
\end{tabular}

Table 1 continued on next page. 
Panel C: Financial Descriptive Measures for Debt Covenant Violation Sample By Year

\begin{tabular}{|c|c|c|c|c|c|c|c|c|c|c|c|}
\hline \# & Variable & Measure & Mean diff. & 2000 & 2001 & 2002 & 2003 & 2004 & 2005 & 2006 & 2007 \\
\hline \multirow[t]{4}{*}{1} & \multirow{4}{*}{$\begin{array}{l}\text { Log of total assets } \\
\text { (company size) }\end{array}$} & Mean & \multirow{4}{*}{ Negative } & 4.921 & 4.774 & 5.265 & 5.584 & 5.931 & 5.877 & 5.903 & 5.408 \\
\hline & & Signif. vs. Compustat $^{5}$ & & $* * *$ & $* * *$ & $* * *$ & $* * *$ & $* * *$ & $* *$ & $* * *$ & ns \\
\hline & & Quantile 25 & & 3.789 & 3.700 & 4.012 & 4.174 & 4.745 & 4.137 & 4.443 & 3.674 \\
\hline & & Quantile 75 & & 6.009 & 5.676 & 6.431 & 6.528 & 7.065 & 7.601 & 7.141 & 7.604 \\
\hline \multirow[t]{4}{*}{2} & \multirow{4}{*}{$\begin{array}{l}\text { Net sales to ending total assets } \\
\text { (asset turnover) }\end{array}$} & Mean & \multirow{4}{*}{ Negative } & 1.143 & 1.262 & 1.138 & 1.138 & 0.921 & 1.053 & 0.863 & 0.960 \\
\hline & & Signif. vs. Compustat & & $* * *$ & $* * *$ & $* * *$ & $* * *$ & ** & $* * *$ & ** & ** \\
\hline & & Quantile 25 & & 0.585 & 0.656 & 0.527 & 0.489 & 0.425 & 0.394 & 0.099 & 0.246 \\
\hline & & Quantile 75 & & 1.496 & 1.672 & 1.532 & 1.525 & 1.207 & 1.574 & 1.338 & 1.302 \\
\hline \multirow[t]{4}{*}{3} & \multirow{4}{*}{$\begin{array}{l}\text { Net income to ending common equity } \\
\text { (return on equity) }\end{array}$} & Mean & \multirow{4}{*}{ Negative } & -0.076 & -0.062 & -0.046 & 0.005 & -0.013 & 0.040 & -0.070 & -0.073 \\
\hline & & Signif. vs. Compustat & & ns & ns & ns & ns & ** & ns & * & ns \\
\hline & & Quantile 25 & & -0.165 & -0.168 & -0.141 & -0.034 & -0.047 & -0.044 & -0.135 & -0.259 \\
\hline & & Quantile 75 & & 0.070 & 0.094 & 0.091 & 0.127 & 0.114 & 0.180 & 0.104 & 0.104 \\
\hline \multirow[t]{4}{*}{4} & \multirow{4}{*}{$\begin{array}{l}\text { Total liabilities to total assets } \\
\text { (financial leverage) }\end{array}$} & Mean & \multirow{4}{*}{ Negative } & 0.548 & 0.536 & 0.560 & 0.539 & 0.525 & 0.525 & 0.553 & 0.546 \\
\hline & & Signif. vs. Compustat & & $* * *$ & $\mathrm{~ns}$ & ns & ns & ns & ns & ns & * \\
\hline & & Quantile 25 & & 0.390 & 0.371 & 0.377 & 0.378 & 0.363 & 0.365 & 0.374 & 0.373 \\
\hline & & Quantile 75 & & 0.722 & 0.698 & 0.753 & 0.682 & 0.707 & 0.672 & 0.772 & 0.752 \\
\hline \multirow[t]{4}{*}{5} & \multirow{4}{*}{$\begin{array}{l}\text { Current assets to current liabilities } \\
\text { (short-term liquidity) }\end{array}$} & Mean & \multirow{4}{*}{ Negative } & 1.985 & 1.982 & 1.937 & 2.196 & 2.147 & 2.074 & 2.237 & 2.087 \\
\hline & & Signif. vs. Compustat & & $* * *$ & $* * *$ & $* * *$ & $* * *$ & $* * *$ & $* *$ & $* * *$ & $* * *$ \\
\hline & & Quantile 25 & & 1.093 & 1.117 & 1.230 & 1.168 & 1.247 & 1.113 & 1.128 & 0.909 \\
\hline & & Quantile 75 & & 2.516 & 2.464 & 2.476 & 2.807 & 2.552 & 2.512 & 2.535 & 2.350 \\
\hline \multirow[t]{4}{*}{6} & \multirow{4}{*}{$\begin{array}{l}\text { Market to book value of common equity } \\
\text { (growth opportunities) }\end{array}$} & Mean & \multirow{4}{*}{ Negative } & 2.606 & 2.689 & 2.079 & 2.403 & 2.918 & 2.593 & 2.436 & 2.272 \\
\hline & & Signif. vs. Compustat & & ns & * & ns & $*$ & ns & ns & ns & ** \\
\hline & & Quantile 25 & & 0.697 & 0.696 & 0.773 & 0.961 & 1.120 & 0.989 & 0.934 & 0.891 \\
\hline & & Quantile 75 & & 2.527 & 2.420 & 2.280 & 2.943 & 2.683 & 3.168 & 3.027 & 2.286 \\
\hline \multirow[t]{4}{*}{7} & Altman Z score & Mean & & 1.498 & 1.794 & 1.912 & 2.678 & 3.200 & 2.791 & 3.590 & 1.506 \\
\hline & (bankruptcy risk) & Signif. vs. Compustat & Negative & $* * *$ & $* * *$ & $* * *$ & $* * *$ & $* * *$ & $* * *$ & $* * *$ & $* * *$ \\
\hline & & Quantile 25 & & 0.188 & 0.601 & 1.023 & 1.171 & 1.457 & 0.604 & 1.445 & -0.133 \\
\hline & & Quantile 75 & & 2.879 & 3.177 & 3.354 & 3.603 & 4.239 & 4.529 & 5.036 & 3.017 \\
\hline 8 & Audit opinion & & & & & & & & & & \\
\hline & Unqualified & Count & & 456 & 281 & 129 & 66 & 47 & 82 & 65 & 48 \\
\hline & Unqualified with additional language & Count & & 112 & 59 & 77 & 73 & 55 & 48 & 46 & 53 \\
\hline & Proportion with additional language & Signif. vs. Compustat $^{6}$ & Positive & $* *$ & $* * *$ & $*$ & $* * *$ & $* * *$ & ns & ns & $*$ \\
\hline 9 & Big 4 auditor & Count & & 377 & 222 & 153 & 116 & 88 & 101 & 76 & 65 \\
\hline & Non-Big 4 auditor & Count & & 196 & 121 & 58 & 25 & 17 & 31 & 35 & 37 \\
\hline & Proportion with Big 4 auditor & Signif. vs. Compustat $^{6}$ & Positive & $* *$ & $* *$ & ** & $* * *$ & ns & $* * *$ & ** & $* * *$ \\
\hline 10 & Covenant action & & & & & & & & & & \\
\hline & No waiver & Count & & 133 & 72 & 48 & 20 & 22 & 23 & 29 & 20 \\
\hline & Waiver & Count & & 440 & 271 & 163 & 121 & 83 & 109 & 82 & 82 \\
\hline 11 & Violation Type & & & & & & & & & & \\
\hline & Debt service & Count & & 5 & 4 & 5 & 0 & 1 & 0 & 0 & 0 \\
\hline & Disclosure of debt default & Count & & 2 & 1 & 2 & 4 & 5 & 9 & 14 & 3 \\
\hline & Technical & Count & & 565 & 337 & 202 & 137 & 97 & 122 & 94 & 97 \\
\hline & Undisclosed & Count & & 1 & 1 & 2 & 0 & 2 & 1 & 3 & 2 \\
\hline 12 & Cumulative excess return-market & Mean & & -0.020 & -0.019 & -0.014 & -0.012 & 0.001 & -0.003 & -0.031 & -0.026 \\
\hline & model-from SEC filing day -1 to 1 & Signif. vs. $0^{8}$ & Negative & $* * *$ & $* * *$ & $* *$ & * & ns & ns & ** & \\
\hline & (short-term investor response) $^{7}$ & Quantile 25 & & -0.078 & -0.072 & -0.061 & -0.051 & -0.043 & -0.032 & -0.041 & -0.035 \\
\hline & & Quantile 75 & & 0.034 & 0.039 & 0.035 & 0.024 & 0.024 & 0.021 & 0.018 & 0.024 \\
\hline & & No. obs. ${ }^{9}$ & & 409 & 390 & 251 & 170 & 106 & 125 & 118 & 109 \\
\hline
\end{tabular}

Table 1 continued on next page. 
Notes to table 1 .

1. Not in compliance with environmental employee, by-law, lease and marketplace regulations and financial institutions not in compliance with reserve requirements.

2. Observation identified by key search terms but not related to debt covenant violations.

3. Subsequent violation by an individual company within the sample period.

4. Buy-sell imbalance ratio equals $\left[\left(\right.\right.$ buy $_{\mathrm{qt}}-$ sell $\left._{\mathrm{qt}}\right) \div\left(\right.$ buy $_{\mathrm{qt}}+$ sell $\left.\left._{\mathrm{qt}}\right)\right]$, where buy $\mathrm{q}_{\mathrm{qt}}$ or sell $\mathrm{qt}_{\mathrm{qt}}$ represents the mean number of trades (col. 4) or total shares traded (col. 7) across q observations of insider shares traded for sample companies in year $\mathrm{t}$.

5. Two-sample $t$ test of covenant violation sample mean less Compustat mean, assuming unequal variances. Tests of significance are whether the difference in means is zero under a two-tailed test: *** = less than $.001, * *=$ less than $.01, *=$ less than $.10, \mathrm{~ns}=$ not significant.

6. Based on a binomial test that the Compustat proportion equals the sample proportion. Two-tailed test of significance.

7. Excess market return based on the market model estimated over 60 months of prior observations.

8. One-sample $t$ test of covenant violation sample mean versus 0 . Two-tailed test of significance. Tests of significance are whether the mean is zero under a two-tailed test: ***=less than $.001, * *=$ less than $.01, *$ $=$ less than $.10, \mathrm{~ns}=$ not significant.

9. Number of observations based on year of filing date. All others based on end of fiscal year. 
Table 2: Cumulative Buy-Sell Imbalance Ratio ${ }^{1}$ and Cumulative Excess Return ${ }^{2}$ Around Debt Covenant Violation Disclosure Month 0

\begin{tabular}{|c|c|c|c|c|c|c|c|c|c|c|c|c|}
\hline \multirow{2}{*}{$\begin{array}{l}\text { Sample } \\
\text { Month }\end{array}$} & \multicolumn{2}{|c|}{ All observations } & \multicolumn{2}{|c|}{ Covenant Waiver } & \multicolumn{2}{|c|}{ No Covenant Waiver } & \multicolumn{2}{|c|}{ Technical Violation } & \multicolumn{2}{|c|}{ Pre-Accel .Filing Rule ${ }^{3}$} & \multicolumn{2}{|c|}{ Post-Accel. Filing Rule } \\
\hline & Cum. BSI & Cum Ex. Ret. & Cum. BSI & Cum Ex. Ret. & Cum. BSI & Cum Ex. Ret. & Cum. BSI & Cum Ex. Ret. & Cum. BSI & Cum Ex. Ret. & Cum. BSI & Cum Ex. Ret. \\
\hline-12 & 0.1507 & -0.0153 & 0.1534 & -0.0101 & 0.2345 & -0.0234 & 0.1628 & -0.0150 & 0.5739 & -0.0160 & -0.7049 & -0.0170 \\
\hline-11 & -0.5173 & -0.0204 & -0.6198 & -0.0146 & 0.2649 & -0.0292 & -0.5163 & -0.0176 & -0.0248 & -0.0200 & -1.4814 & -0.0300 \\
\hline-10 & -0.6597 & -0.0195 & -0.6249 & -0.0162 & -0.2530 & -0.0244 & -0.6619 & -0.0183 & -0.0607 & -0.0168 & -1.6486 & -0.0380 \\
\hline-9 & -1.0233 & -0.0391 & -0.7834 & -0.0315 & -0.8056 & -0.0505 & -1.0226 & -0.0387 & -0.3668 & -0.0428 & -2.0514 & -0.0470 \\
\hline-8 & -1.7105 & -0.0513 & -1.5095 & -0.0348 & -1.1810 & -0.0765 & -1.7136 & -0.0513 & -0.9136 & -0.0588 & -2.7397 & -0.0560 \\
\hline-7 & -1.6366 & -0.0558 & -1.4191 & -0.0381 & -1.1669 & -0.0828 & -1.6472 & -0.0539 & -1.1150 & -0.0583 & -2.5018 & -0.0770 \\
\hline-6 & -1.5690 & -0.0715 & -1.3329 & -0.0499 & -1.1683 & -0.1045 & -1.5919 & -0.0696 & -1.2820 & -0.0783 & -2.2786 & -0.0980 \\
\hline-5 & -1.4067 & -0.0879 & -1.0025 & -0.0739 & -1.4803 & -0.1092 & -1.4298 & -0.0935 & -1.1537 & -0.0963 & -2.5187 & -0.1140 \\
\hline-4 & -1.1866 & -0.0982 & -0.7693 & -0.0795 & -1.3109 & -0.1266 & -1.1880 & -0.1001 & -1.1036 & -0.1053 & -2.1305 & -0.1330 \\
\hline-3 & -1.7064 & -0.0954 & -1.3386 & -0.0840 & -1.1377 & -0.1126 & -1.7190 & -0.0978 & -1.2211 & -0.0936 & -2.7817 & -0.1520 \\
\hline-2 & -2.2432 & -0.1088 & -2.0181 & -0.0880 & -0.7177 & -0.1406 & -2.2620 & -0.1063 & -1.4148 & -0.1086 & -3.5709 & -0.1670 \\
\hline-1 & -2.6246 & -0.1509 & -2.4666 & -0.1213 & -0.7703 & -0.1963 & -2.6421 & -0.1480 & -1.7209 & -0.1586 & -4.0405 & -0.2010 \\
\hline 0 & -2.6197 & -0.1802 & -2.5591 & -0.1393 & -0.2263 & -0.2432 & -2.6379 & -0.1759 & -1.8285 & -0.1916 & -3.9998 & -0.2400 \\
\hline 1 & -2.6689 & -0.1744 & -2.5766 & -0.1321 & -0.5169 & -0.2397 & -2.6644 & -0.1649 & -1.8802 & -0.1844 & -3.9987 & -0.2388 \\
\hline 2 & -2.1979 & -0.1690 & -2.1216 & -0.1177 & 0.0745 & -0.2487 & -2.2106 & -0.1547 & -1.9323 & -0.1669 & -3.2030 & -0.2548 \\
\hline 3 & -2.1902 & -0.1750 & -2.1641 & -0.1184 & 0.5693 & -0.2629 & -2.2185 & -0.1548 & -1.6822 & -0.1769 & -3.3443 & -0.2628 \\
\hline 4 & -1.6040 & -0.1846 & -2.0473 & -0.1200 & 1.4406 & -0.2851 & -1.6322 & -0.1651 & -1.5211 & -0.1839 & -2.7065 & -0.2748 \\
\hline 5 & -1.9130 & -0.1486 & -2.2838 & -0.0829 & 0.7874 & -0.2510 & -1.9455 & -0.1324 & -1.9825 & -0.1331 & -2.5775 & -0.2697 \\
\hline 6 & -1.5860 & -0.1433 & -1.8984 & -0.0856 & 0.8988 & -0.2330 & -1.6272 & -0.1337 & -1.5305 & -0.1206 & -2.6690 & -0.2827 \\
\hline 7 & -1.1892 & -0.1397 & -1.4007 & -0.0908 & 0.6505 & -0.2152 & -1.2302 & -0.1351 & -1.4213 & -0.1112 & -2.4312 & -0.2824 \\
\hline 8 & -1.6273 & -0.1057 & -1.8153 & -0.0641 & 0.4754 & -0.1695 & -1.6689 & -0.1083 & -1.9919 & -0.0675 & -2.9755 & -0.2807 \\
\hline 9 & -1.4336 & -0.0868 & -1.4929 & -0.0461 & 0.1940 & -0.1491 & -1.4795 & -0.0877 & -2.3218 & -0.0347 & -2.5466 & -0.2887 \\
\hline 10 & -1.2191 & -0.0669 & -1.3900 & -0.0230 & 0.8588 & -0.1344 & -1.2738 & -0.0667 & -1.8023 & -0.0098 & -2.5071 & -0.2710 \\
\hline 11 & -0.9257 & -0.0500 & -1.0704 & -0.0115 & 1.2817 & -0.1089 & -0.9821 & -0.0557 & -1.5055 & 0.0190 & -2.2289 & -0.2790 \\
\hline 12 & -0.6914 & -0.0219 & -0.9955 & 0.0065 & 2.1090 & -0.0647 & -0.7474 & -0.0339 & -1.0666 & 0.0592 & -2.0807 & -0.2723 \\
\hline No. obs. & 1,718 & 1,718 & 1,351 & 1,351 & 367 & 367 & 1,651 & 1,651 & 1,157 & 1,157 & 561 & 561 \\
\hline
\end{tabular}

Notes to table 2.

1. Cumulative buy-sell imbalance ratio equals $\Sigma_{\mathrm{t}=-12, \ldots, \mathrm{T}}\left[\left(\right.\right.$ buy $_{\mathrm{qt}}-$ sell $\left._{\mathrm{q}}\right) \div\left(\right.$ buy $_{\mathrm{qt}}+$ sell $\left.\left._{\mathrm{q} t}\right)\right]$, where buy $\mathrm{qt}_{\mathrm{t}}$ or $\mathrm{sell}_{\mathrm{qt}}$ represents the mean across $\mathrm{q}$ observations of insider shares traded for sample companies in disclosure month t.

2. Cumulative excess return equals the cumulative mean excess return over companies in the sample starting at month -12, where excess return is based on the market model, and where the market model parameters are calculated over the prior 60 months.

3. Pre-accelerated filing rule observation occurs before June 30, 2003, following the SEC requirement for insiders to post their trades on Edgar within two days of transaction date. 
Table 3: Time-series Relation Between Buy-Sell Imbalance Ratio ${ }^{1}$ and Excess Return ${ }^{2}$ Around Debt Covenant Violation Disclosure Month 0

\begin{tabular}{|c|c|c|c|c|c|c|c|c|c|}
\hline \multicolumn{10}{|c|}{ Panel A: Event months -12 to 12 Pooled Across All years ${ }^{3}$} \\
\hline Sample/Variable ${ }^{5}$ & All & $\begin{array}{l}\text { High } \\
\text { size }\end{array}$ & Low size & Waiver & $\begin{array}{c}\text { No } \\
\text { waiver }\end{array}$ & $\begin{array}{l}\text { Technical } \\
\text { violation }\end{array}$ & $\begin{array}{c}\text { Other } \\
\text { violation }\end{array}$ & Big 4 auditor & $\begin{array}{c}\text { Non-Big } 4 \\
\text { auditor }\end{array}$ \\
\hline Intercept & 0.0023 & -0.0062 & 0.0085 & 0.0017 & -0.0034 & 0.0004 & -0.0145 & -0.0024 & -0.0055 \\
\hline Signif. & ns & ns & ns & ns & $\mathrm{ns}$ & ns & $\mathrm{ns}$ & $\mathrm{ns}$ & ns \\
\hline $\mathrm{BSI}_{\mathrm{t}}$ & -0.0007 & -0.0014 & 0.0266 & 0.0034 & -0.0058 & 0.0021 & 0.0494 & 0.0008 & -0.0050 \\
\hline Signif. $^{9}$ & ns & ns & ns & ns & ns & ns & $*$ & ns & ns \\
\hline $\mathrm{BSI}_{\mathrm{t}-1}$ & 0.0256 & 0.0136 & 0.0265 & 0.0155 & 0.0097 & 0.0236 & -0.0236 & 0.0235 & -0.0158 \\
\hline Signif. & $* *$ & * & $*$ & ns & ns & ** & ns & $* * *$ & $\mathrm{~ns}$ \\
\hline $\mathrm{BSI}_{\mathrm{t}-2}$ & 0.0227 & -0.0019 & 0.0313 & 0.0172 & 0.0052 & 0.0197 & -0.0192 & 0.0147 & 0.0001 \\
\hline Signif. & $* *$ & ns & $* *$ & $*$ & ns & $*$ & $\mathrm{~ns}$ & $*$ & ns \\
\hline $\mathrm{R}^{2}$ & $37.23 \%$ & $0.34 \%$ & $25.86 \%$ & $17.61 \%$ & $12.05 \%$ & $30.07 \%$ & $15.19 \%$ & $29.90 \%$ & $7.07 \%$ \\
\hline F statistic & 5.35 & 1.02 & 3.56 & 2.57 & 0.21 & 4.15 & 2.01 & 5.91 & 0.52 \\
\hline Signif. & $* * *$ & ns & $* *$ & * & ns & $* *$ & ns & ns & $\mathrm{ns}$ \\
\hline Regr. obs. ${ }^{10}$ & 23 & 23 & 23 & 23 & 23 & 23 & 23 & 23 & 23 \\
\hline Covenant obs. & 1,718 & 859 & 859 & 1,351 & 367 & 1,651 & 67 & 1,198 & 520 \\
\hline \multicolumn{10}{|c|}{ Panel B: Event months -12 to 12 for Pre-Accelerated Filing Period and Post-Accelerated Filing Period ${ }^{6}$} \\
\hline Sample/Variable ${ }^{5}$ & All & All & $\begin{array}{c}\text { Pre- } \\
\text { Accel. }\end{array}$ & $\begin{array}{l}\text { Post- } \\
\text { Accel. }\end{array}$ & Waiver & Waiver & $\begin{array}{l}\text { Technical } \\
\text { Violation }\end{array}$ & $\begin{array}{l}\text { Technical } \\
\text { Violation }\end{array}$ & \\
\hline Intercept & -0.0082 & -0.0011 & 0.0089 & -0.0094 & -0.0084 & -0.0015 & -0.0092 & -0.0022 & \\
\hline Signif. & $*$ & ns & ns & $* * *$ & $* *$ & ns & $* *$ & $\mathrm{~ns}$ & \\
\hline $\mathrm{BSI}_{\mathrm{t}}$ & 0.0012 & 0.0010 & 0.0118 & 0.0004 & -0.0004 & -0.0025 & 0.0021 & 0.0033 & \\
\hline Signif. & $\mathrm{ns}$ & ns & ns & $\mathrm{ns}$ & ns & $\mathrm{ns}$ & $\mathrm{ns}$ & ns & \\
\hline $\mathrm{BSI}_{\mathrm{t}-1}$ & 0.0123 & 0.0152 & 0.0228 & 0.0142 & 0.0119 & 0.0064 & 0.0093 & 0.0110 & \\
\hline Signif. & $\mathrm{ns}$ & $*$ & ns & $* *$ & ns & ns & ns & ns & \\
\hline $\mathrm{BSI}_{\mathrm{t}-2}$ & 0.0133 & 0.0136 & 0.0365 & 0.0020 & 0.0074 & 0.0056 & 0.0098 & 0.0095 & \\
\hline Signif. & * & $*$ & $* *$ & ns & ns & ns & ns & ns & \\
\hline $\mathrm{BSI}_{\mathrm{t}-1} \times$ Pre & 0.0107 & & & & -0.0076 & & 0.0077 & & \\
\hline Signif. & $\mathrm{ns}$ & & & & ns & & ns & & \\
\hline Pre & 0.0149 & & & & 0.0149 & & 0.0149 & & \\
\hline Signif. & $* *$ & & & & $* *$ & & $* *$ & & \\
\hline $\mathrm{R}^{2}$ & $17.48 \%$ & $8.94 \%$ & $17.77 \%$ & $15.01 \%$ & $11.48 \%$ & $2.75 \%$ & $12.05 \%$ & $2.71 \%$ & \\
\hline F statistic & 2.91 & 2.47 & 2.58 & 2.30 & 2.22 & 0.58 & 2.29 & 1.44 & \\
\hline Signif. & $* *$ & $*$ & $*$ & ns & * & ns & * & ns & \\
\hline Regr. obs. & 46 & 46 & 46 & 46 & 46 & 46 & 46 & 46 & \\
\hline Covenant obs. & 1,718 & 1,718 & 1,157 & 561 & 1,351 & 1,351 & 1,651 & 1,651 & \\
\hline \multicolumn{10}{|c|}{ Panel C: Event Months -12 to 12 for Each Year ${ }^{7}$} \\
\hline Sample/Variable ${ }^{5}$ & All & All & $\begin{array}{c}\text { All ex. } \\
2007\end{array}$ & $\begin{array}{c}\text { Pre- } \\
\text { Accel. }\end{array}$ & $\begin{array}{l}\text { Post- } \\
\text { Accel. }\end{array}$ & $\begin{array}{c}\text { Post Accel. } \\
\text { ex. } 2007\end{array}$ & & & \\
\hline Intercept & -0.0031 & -0.0109 & 0.0013 & 0.0052 & -0.0112 & -0.0065 & & & \\
\hline Signif. & * & $* * *$ & ns & $\mathrm{ns}$ & $* * *$ & $* * *$ & & & \\
\hline $\mathrm{BSI}_{\mathrm{t}}$ & 0.0031 & 0.0012 & 0.0044 & 0.0144 & -0.0070 & -0.0054 & & & \\
\hline Signif. & $\mathrm{ns}$ & $\mathrm{ns}$ & $\mathrm{ns}$ & $* *$ & $* *$ & $\mathrm{~ns}$ & & & \\
\hline $\mathrm{BSI}_{\mathrm{t}-1}$ & 0.0074 & -0.0031 & 0.0109 & 0.0170 & 0.0020 & 0.0098 & & & \\
\hline Signif. & $* *$ & $\mathrm{~ns}$ & $* * *$ & $* *$ & ns & $* * *$ & & & \\
\hline $\mathrm{BSI}_{\mathrm{t}-2}$ & 0.0022 & 0.0001 & 0.0029 & 0.0123 & -0.0067 & -0.0061 & & & \\
\hline Signif. & ns & ns & $\mathrm{ns}$ & $*$ & $* *$ & $*$ & & & \\
\hline Year $^{8}$ & yes & no & no & no & no & no & & & \\
\hline Signif. & $* * *$ & na & na & na & na & na & & & \\
\hline $\mathrm{BSI}_{\mathrm{t}-1} \times$ Pre & & 0.0167 & & & & & & & \\
\hline Signif. & & $* *$ & & & & & & & \\
\hline Pre & & 0.0156 & & & & & & & \\
\hline Signif. & & $* * *$ & & & & & & & \\
\hline $\mathrm{R}^{2}$ & $16.22 \%$ & $8.84 \%$ & $4.27 \%$ & $8.28 \%$ & $6.71 \%$ & $7.58 \%$ & & & \\
\hline F statistic & 4.7547 & 4.7643 & 3.5134 & 3.8278 & 3.372 & 3.024 & & & \\
\hline Signif. & $* * *$ & $* * *$ & $* *$ & $* *$ & $* *$ & $* *$ & & & \\
\hline Regr. obs. & 184 & 184 & 161 & 102 & 82 & 59 & & & \\
\hline Covenant obs. & 1,718 & 1,718 & 1,616 & 1,157 & 561 & 459 & & & \\
\hline
\end{tabular}

Notes to table 3 on next page. 
Notes to table 3 .

1. Buy-sell imbalance ratio equals $\left(\right.$ buy $_{\mathrm{qt}}-$ sell $\left._{\mathrm{qt}}\right) \div\left(\right.$ buy $_{\mathrm{qt}}+$ sell $\left._{\mathrm{qt}}\right)$, where buy $\mathrm{q}_{\mathrm{qt}}$ or sell $\mathrm{qt}_{\mathrm{qt}}$ represents the mean across $\mathrm{q}$ observations of insider shares traded for sample companies in disclosure month $\mathrm{t}$.

2. Excess return calculated as mean over companies in the sample starting at month -12, where excess return is based on the market model, and where the market model parameters are calculated over the prior 60 months.

3. Regressions in panel A based on months -12 to 12 for observations pooled across all years.

4. Size based on market capitalization at end of year.

5. $\mathrm{BSI}_{\mathrm{t}}, \mathrm{BSI}_{\mathrm{t}-1}$, and $\mathrm{BSI}_{\mathrm{t}-1}$ refer to the buy-sell imbalance ratio lagged by zero, one, and two months.

6. Regressions in panel $\mathrm{B}$ based on months -12 to 12 for observations pooled for each of the pre- and postaccelerated filing periods.

7. Regressions in panel $\mathrm{C}$ based on months -12 to 12 for observations for each year 2000-2007. Ex. 2007 means that months -12 to 12 for 2007 observations excluded from the sample.

8. Year (panel C) equals a zero-one variable for each of years 2000 to 2006. If "Yes", then Year included in the regression.

9. Tests of significance are whether the coefficient is zero versus non-zero under a two-tailed test of significance: $* * *=$ less than $.001, * *=$ less than $.01, *=$ less than .10, ns $=$ not significant.

10. Regr. observations refers to the number of observations in each regression. Covenant observations refers to the number of debt covenant violation disclosures in month zero for each regression sample. 
Table 4: Cumulative Buy-Sell Imbalance Ratio ${ }^{1}$ and Cumulative Excess Return ${ }^{2}$ Around Debt Covenant Violation Disclosure Month 0: By 8-K Intensity ${ }^{3}$ and $8-\mathrm{K}_{\text {Timing }}{ }^{4}$

\begin{tabular}{|c|c|c|c|c|c|c|c|c|c|c|c|c|}
\hline \multirow{2}{*}{$\begin{array}{l}\text { Measure } \\
\text { Partition } \\
\text { Sample month }\end{array}$} & \multicolumn{3}{|c|}{$\begin{array}{c}\text { Cum BSI } \\
\text { 8-K Intensity }\end{array}$} & \multicolumn{3}{|c|}{$\begin{array}{c}\text { Cum BSI } \\
\text { 8-K Timing }\end{array}$} & \multicolumn{3}{|c|}{$\begin{array}{l}\text { Cum Ex. Ret. } \\
\text { 8-K Intensity }\end{array}$} & \multicolumn{3}{|c|}{$\begin{array}{l}\text { Cum Ex. Ret. } \\
\text { 8-K Timing }\end{array}$} \\
\hline & Low & High & BSI Diff. $^{5}$ & Late & Early & BSI Diff. ${ }^{5}$ & Low & High & Ex. Ret. Diff. ${ }^{6}$ & Late & Early & Ex. Ret. Diff ${ }^{5}$ \\
\hline-12 & 0.3266 & -0.6228 & 0.9494 & 0.0131 & 0.5501 & -0.5370 & -0.0138 & -0.0111 & -0.0027 & -0.0113 & -0.0117 & 0.0004 \\
\hline-11 & 0.0189 & -1.3753 & 0.4448 & -0.0750 & -0.2023 & 0.6644 & -0.0232 & -0.0140 & -0.0092 & -0.0152 & -0.0223 & 0.0071 \\
\hline-10 & -0.1633 & -1.4261 & -0.1313 & -0.4662 & 0.0121 & -0.6056 & -0.0229 & -0.0265 & 0.0036 & -0.0241 & -0.0215 & -0.0026 \\
\hline-9 & -0.5169 & -1.8469 & 0.0671 & -0.7812 & -0.4156 & 0.1127 & -0.0509 & -0.0464 & -0.0045 & -0.0442 & -0.0534 & 0.0092 \\
\hline-8 & -1.0651 & -2.5440 & 0.1489 & -1.6281 & -0.5206 & -0.7419 & -0.0702 & -0.0565 & -0.0137 & -0.0636 & -0.0613 & -0.0023 \\
\hline-7 & -1.2116 & -2.2704 & -0.4200 & -1.7166 & -0.2686 & -0.3405 & -0.0583 & -0.0872 & 0.0288 & -0.0646 & -0.0915 & 0.0269 \\
\hline-6 & -1.6823 & -1.7142 & -1.0270 & -1.3405 & -0.9026 & 1.0101 & -0.0807 & -0.1063 & 0.0257 & -0.0757 & -0.1304 & 0.0547 \\
\hline-5 & -1.4927 & -1.9974 & 0.4729 & -1.4832 & -0.4123 & -0.6330 & -0.0958 & -0.1269 & 0.0311 & -0.0853 & -0.1601 & 0.0748 \\
\hline-4 & -1.1931 & -1.9733 & 0.2754 & -1.4056 & -0.7112 & 0.3765 & -0.1046 & -0.1575 & 0.0529 & -0.1052 & -0.1779 & 0.0727 \\
\hline-3 & -1.8863 & -2.3925 & -0.2740 & -2.1063 & -0.4055 & -1.0064 & -0.0802 & -0.1803 & 0.1001 & -0.1122 & -0.1611 & 0.0489 \\
\hline-2 & -2.4360 & -3.0989 & 0.1568 & -2.8922 & -0.2633 & -0.9281 & -0.0829 & -0.1885 & 0.1056 & -0.1088 & -0.1766 & 0.0678 \\
\hline-1 & -2.8617 & -3.2965 & -0.2282 & -3.0807 & -0.6918 & 0.2401 & -0.1255 & -0.2422 & 0.1167 & -0.1457 & -0.2461 & 0.1004 \\
\hline 0 & -2.3879 & -3.2159 & 0.3933 & -2.8583 & -0.3801 & -0.0893 & -0.1486 & -0.2897 & 0.1411 & -0.1616 & -0.3114 & 0.1498 \\
\hline 1 & -2.3434 & -3.2254 & -0.0539 & -2.6725 & -0.8424 & -0.6482 & -0.1360 & -0.2788 & 0.1428 & -0.1552 & -0.2870 & 0.1318 \\
\hline 2 & -1.8522 & -2.7421 & -0.0080 & -2.3956 & -0.0461 & 0.5195 & -0.1039 & -0.2850 & 0.1811 & -0.1587 & -0.2559 & 0.0972 \\
\hline 3 & -1.5043 & -3.0085 & -0.6142 & -2.6449 & 0.5634 & 0.8588 & -0.1034 & -0.3037 & 0.2003 & -0.1710 & -0.2589 & 0.0879 \\
\hline 4 & -1.0977 & -2.2162 & 0.3856 & -1.9040 & 0.5122 & -0.7921 & -0.1072 & -0.3129 & 0.2058 & -0.1789 & -0.2542 & 0.0752 \\
\hline 5 & -1.4274 & -1.7178 & 0.8282 & -2.0386 & -0.2450 & -0.6227 & -0.0686 & -0.2984 & 0.2299 & -0.1621 & -0.2140 & 0.0520 \\
\hline 6 & -0.9394 & -1.9420 & -0.7122 & -2.3987 & -0.0653 & 0.5399 & -0.0560 & -0.3086 & 0.2525 & -0.1586 & -0.2126 & 0.0540 \\
\hline 7 & -0.7009 & -1.7495 & -0.0460 & -1.7833 & -0.1743 & -0.7244 & -0.0478 & -0.3082 & 0.2605 & -0.1508 & -0.2059 & 0.0551 \\
\hline 8 & -1.1441 & -2.4844 & -0.2917 & -2.2301 & -0.2134 & 0.4077 & 0.0108 & -0.3109 & 0.3216 & -0.1302 & -0.1659 & 0.0357 \\
\hline 9 & -1.5618 & -1.7963 & 1.1059 & -2.2487 & 0.3688 & 0.6008 & 0.0444 & -0.3176 & 0.3620 & -0.1087 & -0.1792 & 0.0706 \\
\hline 10 & -1.3325 & -1.4134 & 0.1535 & -1.9703 & 0.2829 & -0.3643 & 0.0654 & -0.2989 & 0.3642 & -0.0812 & -0.1753 & 0.0941 \\
\hline 11 & -1.1127 & -1.3836 & -0.1898 & -1.8296 & 0.8302 & 0.4065 & 0.0750 & -0.3056 & 0.3806 & -0.0917 & -0.1496 & 0.0578 \\
\hline 12 & -1.0788 & -0.6789 & 0.6707 & -1.1753 & 0.6345 & -0.8500 & 0.1154 & -0.3090 & 0.4244 & -0.0622 & -0.1678 & 0.1055 \\
\hline No. obs. & 545 & 503 & na & 627 & 339 & na & 545 & 503 & na & 627 & 339 & na \\
\hline $\mathrm{t}$-test -12 to $12^{7}$ & & & 0.8983 & & & 0.5588 & & & 0.0063 & & & 0.5233 \\
\hline Mean -12 to $12^{8}$ & & & 0.0822 & & & -0.1259 & & & 0.0170 & & & 0.0042 \\
\hline t-test -12 to $0^{7}$ & & & 0.6863 & & & 0.2458 & & & 0.1022 & & & 0.1295 \\
\hline Mean -12 to $0^{8}$ & & & 0.0637 & & & -0.1906 & & & 0.0109 & & & 0.0115 \\
\hline
\end{tabular}

Notes to table 4 on next page. 
Notes to table 4 .

5. Cumulative buy-sell imbalance ratio equals $\Sigma_{\mathrm{t}=-12, \ldots, \mathrm{T}}\left[\left(\right.\right.$ buy $\left._{\mathrm{qt}}-\operatorname{sell}_{\mathrm{qt}}\right) \div\left(\right.$ buy $\left.\left._{\mathrm{qt}}+\operatorname{sell}_{\mathrm{qt}}\right)\right]$, where buy , $_{\mathrm{qt}}$ or sell $\mathrm{qt}_{\mathrm{qt}}$ represents the mean across q observations of insider shares traded for sample companies in disclosure month $\mathrm{t}$.

6. Cumulative excess return equals the cumulative mean excess return over companies in the sample starting at month 12 , where excess return is based on the market model, and where the market model parameters are calculated over the prior 60 months.

7. 8 -K intensity (high or low) defined relative to the median number $8-\mathrm{K}$ disclosure items.

8. 8 -K Timing (early or late) defined in terms of the proximity of the $8-\mathrm{K}$ filing date in months -12 to 0 to covenant violation month 0. Early or late is relative to the median $8-\mathrm{K}$ filing date in months -12 to 0 .

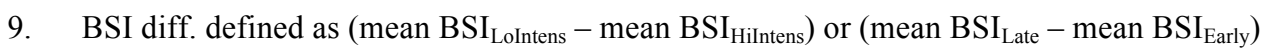

10. Ex. Ret. Diff. defined as (mean Ex. Ret.LoIntens - mean Ex. Ret.HiIntens) or (mean Ex. Ret.Late - mean Ex. Ret.Early).

11. The t-test is a two-sample test of BSI or Ex. Ret. for low minus high intensity companies and late minus early companies in months -12 to 12 and -12 to 0 , respectively.

12. Mean BSI difference defined as the mean of the mean BSI difference in months -12 to 0 and minus the mean BSI difference in months 1 to 12 . 
Table 5: Time-series Relation Between Buy-Sell Imbalance Ratio ${ }^{1}$ and Excess Return ${ }^{2}$ Around Debt Covenant Violation Disclosure Month 0: By 8-K Intensity and 8-K Timing ${ }^{3}$

\begin{tabular}{|c|c|c|c|c|c|c|c|c|}
\hline \multicolumn{9}{|c|}{ Panel A: Event months -12 to 12 Pooled Across All Years ${ }^{4}$} \\
\hline Sample/Variable ${ }^{5}$ & Low Intens & High Intens & Late & Early & & & & \\
\hline Intercept & 0.0087 & -0.0119 & 0.0003 & -0.0069 & & & & \\
\hline Signif. $^{10}$ & $*$ & $* * *$ & $\mathrm{~ns}$ & ns & & & & \\
\hline BSI & -0.0014 & 0.0065 & 0.0081 & 0.0066 & & & & \\
\hline Signif. & ns & ns & ns & ns & & & & \\
\hline $\mathrm{BSI}_{\mathrm{t}-1}$ & 0.0301 & 0.0160 & 0.0131 & 0.0070 & & & & \\
\hline Signif. & $* *$ & $* *$ & ns & ns & & & & \\
\hline $\mathrm{BSI}_{\mathrm{t}-1-2}$ & 0.0278 & 0.0034 & 0.0102 & 0.0188 & & & & \\
\hline Signif. & $* *$ & ns & ns & ns & & & & \\
\hline $\mathrm{R}^{2}$ & $33.10 \%$ & $14.67 \%$ & $10.62 \%$ & $7.93 \%$ & & & & \\
\hline F statistic & 4.63 & 2.26 & 1.87 & 0.55 & & & & \\
\hline Signif. & $* *$ & ns & $\mathrm{ns}$ & ns & & & & \\
\hline No. regression obs. ${ }^{11}$ & 23 & 23 & 23 & 23 & & & & \\
\hline No. sample obs. & 545 & 503 & 627 & 339 & & & & \\
\hline \multicolumn{9}{|c|}{ Panel B: Event months -12 to 12 for 8 -K Intensity and 8-K Timing Sub-Samples ${ }^{6}$} \\
\hline Sample/Variable & Intens/Late & Early & Intens/All & Intens/All & Intens & Intens & Timing/All & Timing/All \\
\hline Intercept & 0.0087 & -0.0119 & -0.0015 & -0.0112 & 0.0003 & -0.0069 & -0.0034 & -0.0068 \\
\hline Signif. & $*$ & $* * *$ & ns & $* * *$ & ns & ns & ns & $\mathrm{ns}$ \\
\hline BSI & -0.0014 & 0.0065 & 0.0023 & 0.0025 & 0.0081 & 0.0066 & 0.0073 & 0.0075 \\
\hline Signif. & $\mathrm{ns}$ & ns & ns & ns & ns & ns & ns & $\mathrm{ns}$ \\
\hline $\mathrm{BSI}_{\mathrm{t}-1}$ & 0.0301 & 0.0160 & 0.0212 & 0.0151 & 0.0131 & 0.0070 & 0.0079 & 0.0056 \\
\hline Signif. & $* *$ & $* *$ & $* * *$ & $*$ & ns & ns & ns & $\mathrm{ns}$ \\
\hline $\mathrm{BSI}_{\mathrm{t}-2}$ & 0.0278 & 0.0034 & 0.0130 & 0.0118 & 0.0102 & 0.0188 & 0.0142 & 0.0145 \\
\hline Signif. & $* *$ & ns & $*$ & $*$ & ns & $\mathrm{ns}$ & $*$ & $\mathrm{~ns}$ \\
\hline $\mathrm{BSI}_{\mathrm{t}-1} \times$ Dum & & & & 0.0194 & & & & 0.0074 \\
\hline Signif. & & & & $* * *$ & & & & $\mathrm{~ns}$ \\
\hline Dum $^{7}$ & & & & 0.0177 & & & & 0.0073 \\
\hline Signif. & & & & ns & & & & ns \\
\hline $\mathrm{R}^{2}$ & $33.10 \%$ & $14.67 \%$ & $18.68 \%$ & $35.32 \%$ & $10.62 \%$ & $7.93 \%$ & $2.59 \%$ & $0.71 \%$ \\
\hline F statistic & 4.63 & 2.26 & 4.45 & 5.91 & 1.87 & 0.55 & 1.40 & 1.06 \\
\hline Signif. & $* *$ & ns & $* * *$ & $* * *$ & ns & ns & ns & ns \\
\hline No. regression obs. & 46 & 46 & 46 & 46 & 46 & 46 & 46 & 46 \\
\hline \multicolumn{9}{|c|}{ Panel C: Event Months -12 to 12 for Each Year ${ }^{8}$} \\
\hline Sample/Variable & Intens/All & Intens/All & Timg/All & Timg/All & & & & \\
\hline Intercept & -0.0084 & -0.0156 & -0.0065 & -0.0083 & & & & \\
\hline Signif. & $* *$ & $* * *$ & $* * *$ & $* * *$ & & & & \\
\hline BSI & -0.0071 & -0.0083 & -0.0073 & -0.0074 & & & & \\
\hline Signif. & $\mathrm{ns}$ & $\mathrm{ns}$ & $*$ & $*$ & & & & \\
\hline $\mathrm{BSI}_{\mathrm{t}-1}$ & -0.0031 & -0.0049 & 0.0114 & 0.0156 & & & & \\
\hline Signif. & $\mathrm{ns}$ & $\mathrm{ns}$ & $* * *$ & $* * *$ & & & & \\
\hline $\mathrm{BSI}_{\mathrm{t}-2}$ & 0.0049 & 0.0038 & -0.0004 & -0.0004 & & & & \\
\hline Signif. & ns & ns & ns & ns & & & & \\
\hline Year $^{9}$ & yes & yes & yes & yes & & & & \\
\hline Signif. & na & na & na & na & & & & \\
\hline $\mathrm{BSI}_{\mathrm{t}-1} \times$ Dum & & 0.0128 & & 0.0037 & & & & \\
\hline Signif. & & $*$ & & ns & & & & \\
\hline Dum $^{7}$ & & 0.0008 & & -0.0084 & & & & \\
\hline Signif. & & ns & & ns & & & & \\
\hline $\mathrm{R}^{2}$ & $4.31 \%$ & $4.71 \%$ & $6.93 \%$ & $7.00 \%$ & & & & \\
\hline F statistic & 2.14 & 2.06 & 4.02 & 3.59 & & & & \\
\hline Signif. & ** & $* *$ & $* * *$ & $* * *$ & & & & \\
\hline No. regression obs. & 280 & 280 & 448 & 448 & & & & \\
\hline No. sample obs. & 1,610 & 1,610 & 1,610 & 1,610 & & & & \\
\hline
\end{tabular}

Notes to table 5 on next page. 
Notes to table 5 .

1. Buy-sell imbalance ratio equals $\left(\right.$ buy $_{\mathrm{qt}}-$ sell $\left._{\mathrm{qt}}\right) \div\left(\right.$ buy $_{\mathrm{qt}}+$ sell $\left._{\mathrm{qt}}\right)$, where buy $\mathrm{qt}_{\mathrm{qt}}$ or sell $\mathrm{qt}_{\mathrm{qt}}$ represents the mean across $\mathrm{q}$ observations of insider shares traded for sample companies in disclosure month $t$.

2. Excess return calculated as mean over companies in the sample starting at month -12, where excess return is based on the market model, and where the market model parameters are calculated over the prior 60 months.

3. 8-K Intensity (high or low) defined relative to the median number $8-\mathrm{K}$ disclosure items, and 8-K Timing (early or late) defined in terms of the proximity of the $8-\mathrm{K}$ filing date in months -12 to 0 to covenant violation month 0 .

4. Regressions in panel A based on months -12 to 12 for observations pooled across all years.

5. $\quad \mathrm{BSI}_{\mathrm{t}}, \mathrm{BSI}_{\mathrm{t}-1}$, and $\mathrm{BSI}_{\mathrm{t}-2}$ refer to the buy-sell imbalance ratio lagged by zero, one, and two months.

6. Regressions in panel $\mathrm{B}$ based on months -12 to 12 for observations pooled for each of the $8-\mathrm{K}$ intensity and 8-K timing partitions.

7. Dum equals Intens or Timg, where Intens equals 1 for low $8-\mathrm{K}$ intensity companies, 0 otherwise, and Timg equals 1 for late 8 -K companies, 0 otherwise.

8. Regressions in panel $\mathrm{C}$ based on months -12 to 12 for observations for each year 2000-2007.

9. Year (panel C) equals a zero-one variable for each of years 2000 to 2006.

10. Tests of significance are whether the coefficient is zero versus non-zero under a two-tailed test of significance: $* * *=$ less than $.001, * *=$ less than $.01, *=$ less than $.10, \mathrm{~ns}=$ not significant.

11. Regr. observations refers to the number of observations in each regression. Covenant observations refers to the number of debt covenant violation disclosures in month zero for each regression sample. 
Table 6: Gains to Insiders from Buying and Selling in Months -12 to 12 Relative to Debt Covenant Violation Disclosure Month 0

\begin{tabular}{|c|c|c|c|c|c|c|c|c|c|c|c|c|c|}
\hline \multirow{2}{*}{$\begin{array}{l}\text { Gain/loss calculation }^{1} \\
\text { Sample }^{2}\end{array}$} & \multirow[b]{2}{*}{ Type $^{3}$} & \multicolumn{3}{|c|}{ Pre-disclosure loss in months -11 to -1} & \multicolumn{3}{|c|}{ Post-disclosure gain in months 1 to 12} & \multicolumn{3}{|c|}{ Pre-disclosure loss over 3 months } & \multicolumn{3}{|c|}{ Post-disclosure gain over 3 months } \\
\hline & & Sum $^{4}$ & Mean $^{5}$ & 25 -tile ${ }^{6}$ & Sum & Mean & 75-tile & Sum & Mean & 25-tile & Sum & Mean & 75 -tile \\
\hline \multirow[t]{3}{*}{ All } & A & $-220,934,461$ & $-18,925$ & $-2,603$ & $173,615,340$ & 10,486 & 2,911 & $-133,730,474$ & $-10,577$ & -863 & $-19,433,901$ & $-1,174$ & 1,909 \\
\hline & $\mathrm{D}$ & $-1,791,164,545$ & $-82,349$ & $-17,228$ & $61,933,134$ & 1,580 & 502 & $-946,853,896$ & $-40,926$ & $-8,265$ & $15,057,901$ & 384 & 157 \\
\hline & $A \& D$ & $-2,012,099,006$ & $-60,197$ & $-8,967$ & $235,548,474$ & 4,224 & 1,022 & $-1,080,584,369$ & $-30,201$ & $-4,065$ & $-4,376,000$ & -78 & 364 \\
\hline \multirow[t]{2}{*}{$\mathrm{High}_{\mathrm{Size}}{ }^{7}$} & A & $-172,111,094$ & $-60,903$ & $-9,313$ & $199,887,571$ & 41,853 & 10,736 & $-48,383,655$ & $-15,714$ & $-1,567$ & $77,316,113$ & 16,188 & 8,966 \\
\hline & $\mathrm{D}$ & $-1,792,480,720$ & $-126,124$ & $-28,574$ & $140,848,057$ & 6,437 & 1,224 & $-832,783,401$ & $-55,206$ & $-9,979$ & $42,241,010$ & 1,931 & 230 \\
\hline \multirow[t]{2}{*}{ Low Size } & A & $-47,672,422$ & $-5,480$ & $-1,409$ & $-25,441,472$ & $-2,184$ & 1,294 & $-83,397,367$ & $-8,858$ & -726 & $-97,224,661$ & $-8,346$ & 673 \\
\hline & $\mathrm{D}$ & $1,307,564$ & 174 & $-6,472$ & $-78,939,254$ & $-4,574$ & 44 & $-114,052,730$ & $-14,186$ & $-6,152$ & $-27,153,164$ & $-1,573$ & 4 \\
\hline \multirow[t]{2}{*}{ Waiver } & A & $-115,914,062$ & $-12,882$ & $-2,459$ & $344,857,463$ & 27,365 & 2,323 & $-132,799,587$ & $-13,467$ & -727 & $106,183,400$ & 8,426 & 1,385 \\
\hline & D & $-1,104,466,780$ & $-68,405$ & $-13,083$ & $2,247,745$ & 66 & 457 & $-540,415,283$ & $-31,044$ & $-7,867$ & $-66,086,278$ & $-1,937$ & 0 \\
\hline \multirow[t]{2}{*}{ No waiver } & A & $-105,020,399$ & $-39,245$ & $-3,114$ & $-171,242,122$ & $-43,298$ & 4,895 & $-930,886$ & -334 & $-1,327$ & $-125,617,300$ & $-31,762$ & 5,051 \\
\hline & $\mathrm{D}$ & $-686,697,765$ & $-122,515$ & $-39,371$ & $59,685,389$ & 11,735 & 781 & $-406,438,613$ & $-70,956$ & $-10,538$ & $81,144,179$ & 15,954 & 595 \\
\hline \multirow[t]{2}{*}{ Technical violation } & A & $-192,114,159$ & $-16,815$ & $-2,426$ & $131,277,759$ & 8,038 & 2,594 & $-127,460,319$ & $-10,283$ & -794 & $-60,291,273$ & $-3,692$ & 1,740 \\
\hline & $\mathrm{D}$ & $-1,785,996,165$ & $-83,178$ & $-17,078$ & $60,460,211$ & 1,552 & 492 & $-942,472,243$ & $-41,244$ & $-8,217$ & $11,202,402$ & 288 & 154 \\
\hline \multirow[t]{2}{*}{ Other violation } & A & $-28,820,303$ & $-115,744$ & $-22,505$ & $42,337,582$ & 188,167 & 321,460 & $-6,270,154$ & $-25,181$ & $-4,923$ & $40,857,372$ & 181,588 & 319,919 \\
\hline & D & $-5,168,380$ & $-18,525$ & $-28,601$ & $1,472,923$ & 6,086 & 4,060 & $-4,381,653$ & $-15,374$ & $-24,165$ & $3,855,498$ & 15,932 & 3,780 \\
\hline \multirow[t]{2}{*}{ Violation/no waiver ${ }^{8}$} & A & $-85,611,664$ & $-34,929$ & $-2,393$ & $-212,516,364$ & $-56,914$ & 3,481 & $2,523,205$ & 986 & $-1,065$ & $-165,925,750$ & $-44,436$ & 3,614 \\
\hline & $\mathrm{D}$ & $-686,508,227$ & $-125,275$ & $-44,258$ & $56,540,386$ & 11,308 & 730 & $-406,635,480$ & $-72,652$ & $-10,656$ & $79,317,500$ & 15,864 & 536 \\
\hline \multirow[t]{2}{*}{ Big 4} & A & $-151,596,096$ & $-21,920$ & $-3,052$ & $116,857,664$ & 10,202 & 4,362 & $4,735,494$ & 632 & -872 & $-1,519,636$ & -133 & 3,153 \\
\hline & $\mathrm{D}$ & $-1,633,831,516$ & $-88,829$ & $-18,409$ & $126,398,648$ & 3,619 & 638 & $-882,832,235$ & $-45,285$ & $-8,902$ & $49,311,939$ & 1,412 & 170 \\
\hline \multirow[t]{2}{*}{ Non-Big 4} & A & $-69,338,365$ & $-14,573$ & $-2,147$ & $56,757,677$ & 11,122 & 933 & $-138,465,968$ & $-26,887$ & -847 & $-17,914,264$ & $-3,511$ & 397 \\
\hline & $\mathrm{D}$ & $-157,333,030$ & $-46,853$ & $-12,066$ & $-64,465,514$ & $-15,087$ & 2 & $-64,021,661$ & $-17,584$ & $-5,891$ & $-34,254,039$ & $-8,016$ & 0 \\
\hline \multirow[t]{2}{*}{2000} & A & $-73,708,855$ & $-28,569$ & $-1,623$ & $34,003,973$ & 23,290 & 3,361 & $-81,741,691$ & $-28,481$ & -985 & $8,416,634$ & 5,765 & 1,574 \\
\hline & $\mathrm{D}$ & $-1,078,658,066$ & $-257,990$ & $-139,092$ & $-3,256,990$ & $-4,112$ & 0 & $-532,088,834$ & $-120,165$ & $-70,545$ & $-4,142,023$ & $-5,230$ & 0 \\
\hline \multirow[t]{2}{*}{2001} & A & $-24,417,930$ & $-13,446$ & -354 & $-129,933,405$ & $-37,893$ & 3,351 & $-3,669,117$ & $-1,835$ & -270 & $-95,672,108$ & $-27,901$ & 2,069 \\
\hline & D & $-65,094,032$ & $-27,688$ & $-6,434$ & $93,130,224$ & 24,265 & 3,333 & $-47,865,553$ & $-19,706$ & $-6,769$ & $119,681,170$ & 31,183 & 1,718 \\
\hline \multirow[t]{2}{*}{2002} & A & $-7,729,364$ & $-6,169$ & $-1,938$ & $157,649,392$ & 54,682 & 2,410 & $-3,405,663$ & $-2,572$ & $-1,255$ & $74,723,874$ & 25,919 & 2,507 \\
\hline & D & $-103,327,137$ & $-57,725$ & $-15,110$ & $-35,637,410$ & $-7,160$ & 329 & $-12,638,895$ & $-6,922$ & $-4,963$ & $-22,879,338$ & $-4,597$ & 249 \\
\hline \multirow[t]{2}{*}{2003} & A & $-9,323,125$ & $-21,383$ & $-1,124$ & $22,982,669$ & 20,970 & 2,671 & $-6,113,453$ & $-13,525$ & -447 & $1,748,684$ & 1,596 & 1,657 \\
\hline & D & $-21,747,125$ & $-17,003$ & $-13,514$ & $-6,065,115$ & $-2,006$ & 4,298 & $4,371,396$ & 2,818 & $-2,566$ & $1,031,532$ & 341 & 2,679 \\
\hline \multirow[t]{2}{*}{2004} & A & $-8,662,685$ & $-11,250$ & $-1,296$ & $-10,030,780$ & $-15,922$ & 678 & $-3,120,748$ & $-3,711$ & -226 & $-970,989$ & $-1,541$ & 263 \\
\hline & D & $2,739,175$ & 1,440 & $-5,717$ & $35,538,364$ & 10,733 & 1,497 & $5,532,276$ & 2,839 & $-2,803$ & $-34,542,814$ & $-10,433$ & 0 \\
\hline \multirow[t]{2}{*}{2005} & A & $-9,740,723$ & $-15,942$ & $-6,211$ & $-2,378,150$ & $-2,538$ & 61 & $-7,122,450$ & $-11,129$ & $-2,442$ & $-1,553,422$ & $-1,658$ & 203 \\
\hline & $\mathrm{D}$ & $-47,287,319$ & $-22,475$ & $-8,312$ & $-879,230$ & -299 & 1,236 & $-583,760$ & -262 & $-4,094$ & $-6,154,188$ & $-2,096$ & 316 \\
\hline \multirow[t]{2}{*}{2006} & A & $-8,894,960$ & $-3,837$ & $-5,090$ & $93,875,420$ & 25,740 & 5,767 & $-9,958,785$ & $-3,864$ & $-1,132$ & $59,096,964$ & 16,204 & 4,134 \\
\hline & D & $-451,313,509$ & $-58,438$ & $-15,821$ & $-20,465,516$ & $-1,043$ & 0 & $-362,480,021$ & $-43,714$ & $-6,680$ & $-37,936,383$ & $-1,933$ & 0 \\
\hline 2007 & A & $-67,648,119$ & $-55,133$ & $-15,403$ & $-6,272,058$ & $-6,977$ & 94 & $-14,143,498$ & $-11,181$ & $-1,316$ & $-6,434,981$ & $-7,158$ & 0 \\
\hline & $\mathrm{D}$ & $-26,097,881$ & $-65,082$ & $-8,058$ & $1,889,595$ & 3,098 & 2,555 & $-1,003,355$ & $-2,406$ & -158 & 627,137 & 1,028 & -828 \\
\hline
\end{tabular}


Notes to table 6 .

1. Gain/loss calculation: Trading rule 1=Pre-disclosure loss in months -11 to -1 equals value of pre-disclosure insider transaction times cumulative excess return beginning one month after transaction and ending at month -1 ; post-disclosure gain in months 1 to 12 equals value of insider transaction times cumulative excess return beginning one month after post-disclosure transaction and ending at month 12 . Trading rule $2=$ Pre-disclosure loss/gain over three months assumes a maximum of a three-month holding period, beginning one month after the transaction.

2. Sample: All=all debt covenant violations. Other sub-samples are based on waiver decision, violation type, firm size, and auditor. Year based on the calendar year of the filing date of a covenant violation.

3. Type: $\mathrm{A}=$ acquisition, $\mathrm{D}=$ disposition

4. Sum $=$ sum of insider gains (losses) over all insider transactions.

5. Mean=mean insider gain (loss) per insider transaction.

6. 25-tile or 75 -tile: $25^{\text {th }}$ and $75^{\text {th }}$ percentiles across distribution of insider transactions.

7. Size based on market capitalization at end of fiscal year.

8. Violation/no waiver: A sub-sample of covenant violations (technical or non-technical) for which the lender did not grant a waiver. 